\title{
COP26 Futures We Want - UK Country Profile
}

The purpose of this region profile was to provide an evidence base to inform the production of Net Zero Future visions. A consolidated version of material contained here was used as stimulus for in-country workshops and creative translational approaches that developed a plausible vision for each country. This document provides a selection of relevant evidence for the sectors and themes identified through the scoping exercise.

\section{Part A: Executive Summary}

The UK has committed to bringing its greenhouse gas (GHG) emissions to net zero by 2050 , as well as committing to the intermediate target of reducing its emissions by $78 \%$ by 2035 , compared to 1990 levels. This will require strong mitigation measures across all economic sectors, as set out by the Climate Change Committee's recommendations in the $6^{\text {th }}$ Carbon Budget.

Innovations across important UK sectors will help to achieve these targets while also boosting economic activity, ensuring a just transition with more green jobs, and offering important co-benefits for a more resilient future.

Currently, the UK's largest GHG emitting sectors are electricity \& heating, transport, buildings and agriculture. The UK has already made considerable progress on decarbonising its energy system, primarily through the phasing out of coal power and investment in renewable energy sources such as wind and solar. This trend looks set to continue, with offshore wind energy now cheaper than gas-fired and nuclear power.

In the transport sector, significant progress has been made on the transition to electric vehicles (EVs), and the UK has now committed to phase out the sale of new petrol and diesel cars by 2030 . Significant opportunities for emissions reduction are possible through encouraging a behavioural shift towards alternative forms of (public) transport and active travel and reducing demand for private car transport. Re-designing UK cities to include more dense, mixed use, and attractive low traffic neighbourhoods that prioritise walking and cycling will help enable active travel. Significant opportunities for emission reduction also exist in housing. Requiring all new-builds to meet Passivhaus standards can deliver higher living standards, cleaner air, and new job opportunities. However, the UK has one of the oldest domestic buildings stocks in Europe, so retrofitting existing homes with heat pumps, mechanical ventilation heat recovery systems, better windows, and insulation, can ensure that this important challenge is met and that the burden is shared equally. Such measures will reduce energy consumption helping to lower energy bills while keeping homes warm during the winter months.

Given enough rapid research and development, even sectors in which abatement is difficult, such as aviation, cement and steel, provide opportunities for innovation. For example, innovation in the aviation sector, where the UK is a world-leader, could include battery-powered aircraft, sustainable aviation fuels, and the use of hydrogen. 
Greenhouse gas removals (GGR), to sequester the remaining emissions from hard-todecarbonise sectors, will also be essential for the UK to reach its net zero targets. These include Nature-based Solutions, such as tree planting and peatland restoration, which can contribute to improving biodiversity at the same time as reducing emissions. However, many technological GGR solutions, such as carbon capture \& storage (CCS) or direct air capture (DAC) are still in their infancy and will require significant research and investment, as well as substantial international collaboration, to be deployed at any climatically relevant scales. The UK's research and financing capabilities to bring such technologies to maturity are an important part of the leading international role the UK can play in global mitigation.

The most pressing climate risks the UK faces before 2050 involve flooding, overheating, potential water scarcity. The complex interdependencies between physical infrastructure networks e.g., transportation systems, and social infrastructure e.g., healthcare exacerbate the potential for cascading climate impacts. Certain regions will also face greater risks due to geographic and/or socioeconomic constraints.

Coastal and low-lying regions of the UK i.e., those within floodplains, may be sharply impacted by both climate and the risks posed by moving to a net zero pathway (transition risks), as they have slower population and employment growth and higher rates of deprivation than other areas of the country. Difficulties procuring insurance and a much lower capability to prepare for or respond to future climate risk will mean that these areas could be hard-hit by rising sea levels and increased probability of flooding and erosion in the second half of the century. However, even in a future in which global warming has been limited to well below $2^{\circ} \mathrm{C}$, the UK could feasibly expect $37 \mathrm{~cm}$ of sea-level rise by $2060,67 \mathrm{~cm}$ by 2100 , a $10 \%$ chance each year of extreme precipitation events, a $50 \%$ chance of heatwaves as severe as in 2018/2019, and severe water shortages. This highlights the extent to which meeting its net zero target does not mean the UK can safely avoid adaptation.

Furthermore, failure to adapt to climate change could imperil the UK's net-zero strategy overall. Deep peats, upland peats, forests, and soils could all become net emitters of carbon dioxide without immediate action to build resilience in these vital ecosystems.

Measures such as rewilding, increasing the coverage of diverse forests, greening cities to reduce urban heat islands, restoring wetlands, fens, and floodplains, replenishing coastal habitats, and extending the coverage of hedgerows to increase biodiversity and carbon storage while protecting against erosion can provide a buffer against climaterelated shocks and contribute to future resilience.

The profile is structured in three main sections: 1 . country context, covering economic and development context, and current greenhouse gas emissions; 2. physical climate change, covering risks, adaptation, and opportunities; and 3. development-compatible transition, covering risks, mitigation, and opportunities. The latter half of section 3 has a focus on 7 priority sectors for the UK. These sectors have been identified in discussion with the UK Expert Committee members and include: aviation, financial services, GGR, buildings/built environment, energy/electricity generation, surface transport, and agriculture/land use. 


\section{Part B: Expert Committee Inputs}

\section{Country Context:}

\section{1.a Economic Context}

\section{1.a.i Sectors that contribute most to the country's GDP}

The UK is a post-industrial country, a fact reflected in the sectors that contribute most to its GDP. Between 2009-2019 the UK's predominant economic sector was services e.g., wholesale and retail, hotels and catering, real estate, business, administration, and public services, accounting for $71 \%$ of GDP in $2019^{1}$. Manufacturing accounted for $10 \%$ of GDP, construction 6\%, financial and insurance services (separated from other services by the ONS) $8 \%$, and non-manufacturing production and agriculture $5 \%$, including North Sea Oil and Gas.

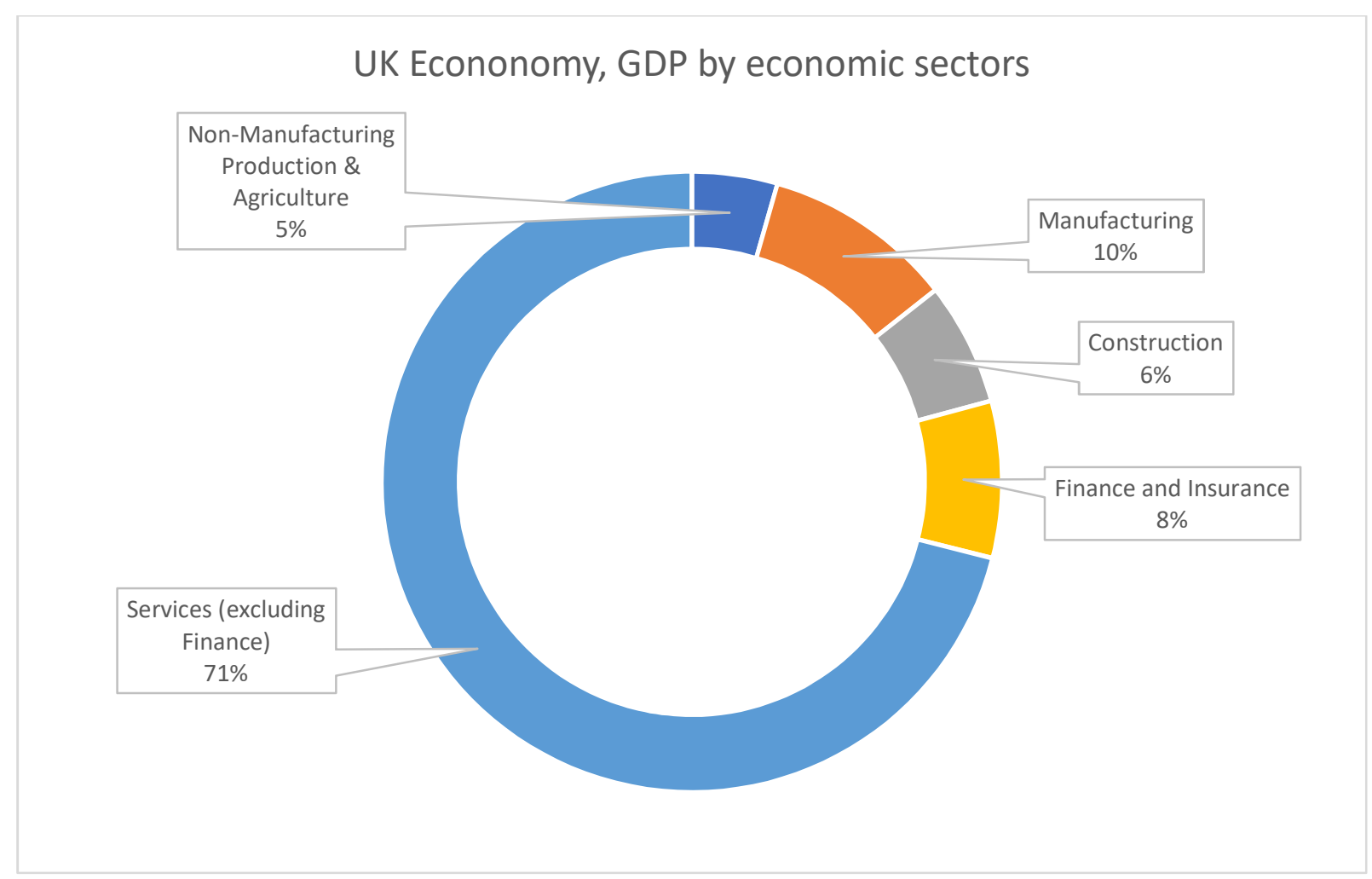

Figure 1: UK economy, GDP by sectors, 2019. Based on ONS (2021) Breakdown of contributions to UK economy by sector, Whole Economy (aggregated breakdown) Chained Volume Measure GVA ${ }^{1}$

\section{1.a.ii Sectors that represent growth areas for the country economically (in absolute} terms, but also as a proportion of GDP)

The current economic outlook for the UK is difficult to interpret in an academically rigorous way, particularly considering ongoing disruption from the COVID-19 pandemic and Brexit. ${ }^{2}$ Studies have indicated that to achieve a net-zero future, the UK needs to decouple GDP and economic growth from GHG emissions at rates significantly higher 
than already achieved. ${ }^{3}$ The UK has the potential to emerge from the pandemic stronger and more resilient than before but needs to tackle social inequality, climate change and damage to nature. By creating the conditions for a green recovery, supporting the societal transition to net-zero, investing in zero-carbon technology and resilient, sustainable infrastructure, deploying Nature-based Solutions (NbS), and showing global leadership, the UK can ensure that this challenge is met. ${ }^{4}$ The wide range of options for ensuring these changes is discussed in more detail in the sections below.

In a green growth scenario, there will be clear clean growth opportunities in certain sectors (notably: finance, transport, aviation, agriculture, industry, energy and housing). ${ }^{5}$ In addition, there are clear areas where the UK has high potential to capture market share in a zero carbon economy (ZCE) including low-carbon services, low emission vehicles, infrastructure, fuel cells, energy storage, and other low-carbon goods and services. ${ }^{6}$ Furthermore, it has a medium potential for capturing market share in energy efficient products, and low-carbon electricity, but a low-to-medium potential in capturing energy from waste and biomass. Finally, target industries for growth also include high value manufacturing, and digital.

\section{1.a.iii. Major trade-flows (goods and services) in and out of the country today}

In 2019, the UK was a net importer of goods, with imports exceeding exports by $£ 175 \mathrm{~B}$. Total non-EU exports totalled £197B, while EU exports totalled £169.8B. Its top ten exports of goods in 2019 were mechanical appliances, motor vehicles, precious metals, mineral fuels, electronic equipment, pharmaceutical products, measuring devices and gauges, aircraft, organic chemicals, and art and antiques ${ }^{7}$ (Figure 2).

Total non-EU imports totalled £275.6B, and total EU imports totalled £266.1B. Precious metals, mechanical appliances, motor vehicles, electronic equipment, mineral fuels, pharmaceutical products, measuring devices and gauges, plastics and plastics products, knitwear, and clothes, were the UK's ten largest import goods in 2019 (Figure 3).

In terms of services exported, in 2017 , the UK contributed to approximately $14.1 \%$ of the global insurance market, and approximately $19.9 \%$ of the global financial services market. Therefore, $14.9 \%$ of UK insurance was exported and $30.7 \%$ of the UK financial services were exported 8 . 


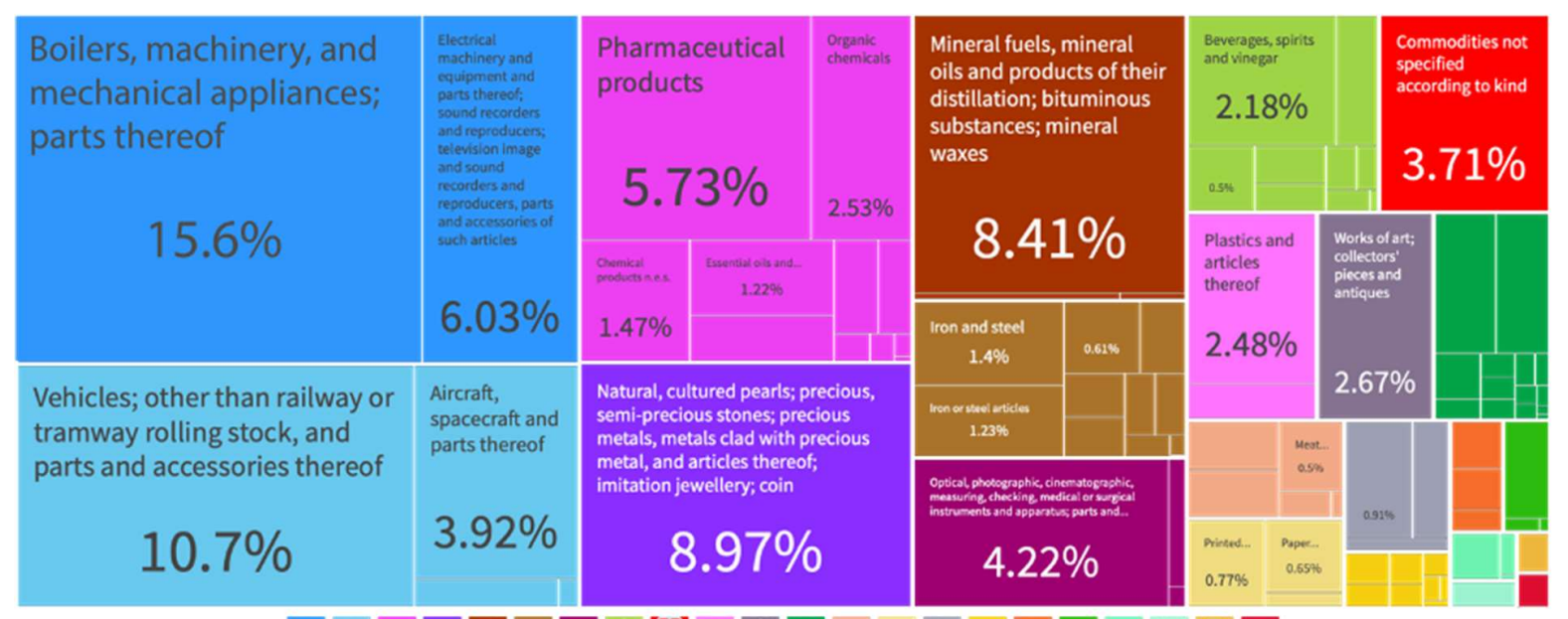

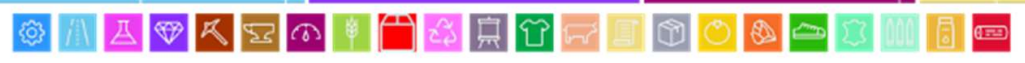

Figure 2: UK exports (goods) (2019). In 2019, exports totalled more than $£ 367 B, 13 \%$ of the country's GDP that year. The Observatory of Economic Complexity. Link

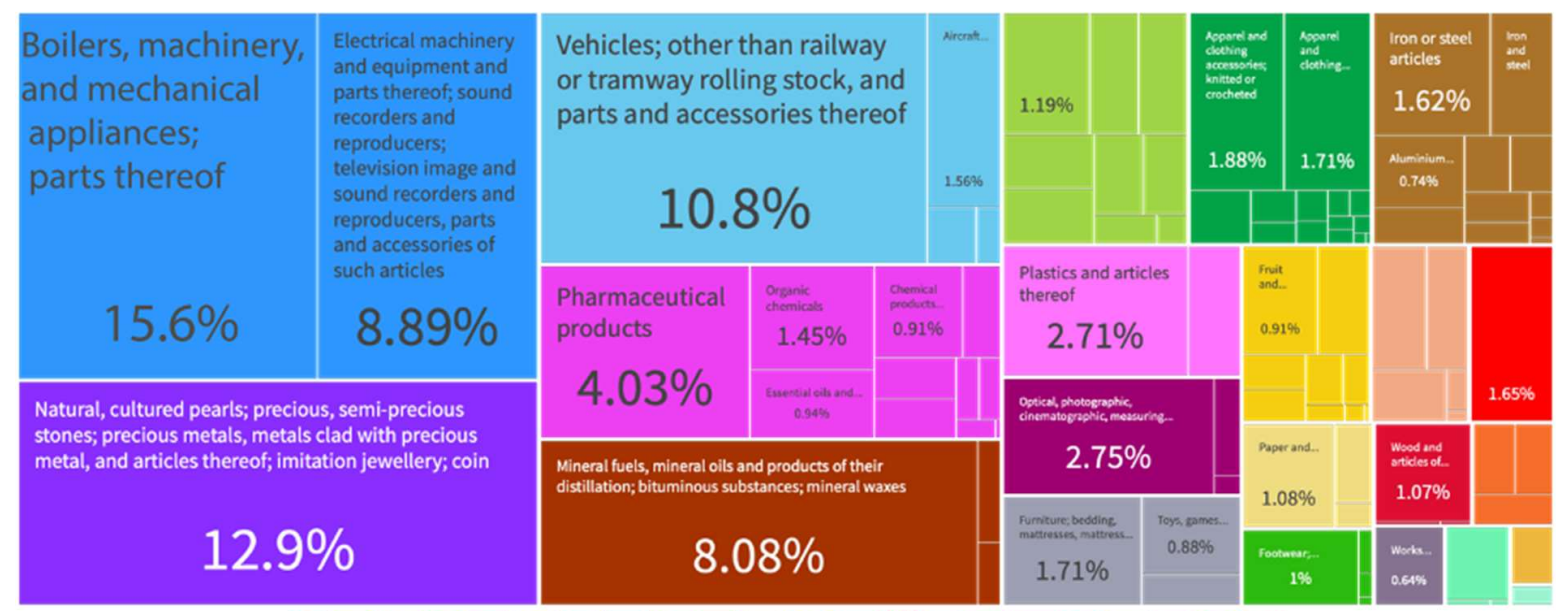

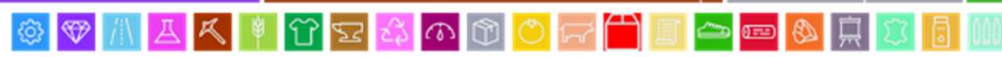

Figure 3: Imports to the UK (goods), 2019, totalled £542B. The UK was a net importer in 2019 , with imports exceeding exports by £175B. The Observatory of Economic

Complexity. Link

\section{1.b Development Context}

\section{1.b.i What are the key development indices for this country?}

In 2019, the UK's Human Development Index (HDI) ranked $13^{\text {th }}$ in the world, at $0.932^{9}$, which puts the country in the very high human development category. Between 1990 and 2019 , the UK's HDI value increased by $19.3 \%$ from 0.781 to 0.932 . The UK's Gini 
coefficient, a measure representing the income or wealth inequality within a nation, was $34.6 \%$ in $2020 .{ }^{10}$ This places the UK among countries with the highest levels of income inequality in the EU.

\section{1.b.ii What are the priorities and barriers to enabling the country's sustainable, inclusive and resilient growth?}

Rapidly transitioning to a low-carbon economy, supporting the societal transition to netzero, investing in zero-carbon technology and resilient, sustainable infrastructure, deploying $\mathrm{NbS}$, and tackling social inequality through inclusive growth are priorities to enabling the UK's sustainable growth ${ }^{11}$.

There are several barriers to the opportunities of moving to a zero carbon economy $(Z C E)^{12}$ : (i) There is uncertainty due to a lack of clear policy for key technologies. For example, higher renewable energy outputs could reduce the potential for bioenergy with carbon capture and storage (BECCS). Without clear incentives investors may be wary due to the high capital expenditure involved. Therefore, there is a strong need for clear government involvement in supporting new projects and increasing the confidence of potential private stakeholders who would need to assume an increasing role as projects get off the ground. ${ }^{13}$ Ultimately, the ability to transition to a ZCE depends on the emergence of a comprehensive governance system that can coordinate the interests of diverse stakeholders, regulate the different policy arms of transition and address the farreaching sociocultural and political issues that will be affected. ${ }^{14}$ (ii) Low-emission vehicles may face difficulties scaling up in the UK, despite good research and development. (iii) The UK has unusually old housing stock and both improving the energy efficiency of this housing stock and transitioning to low carbon energy sources present logistical barriers ${ }^{15}$. (iv) Strategic overview of freight transport will also be important in tackling emissions from freight. ( $v$ ) There may be regulatory barriers that hinder small and medium sized enterprises (SMEs) in developing energy efficient products and favour larger entities, limiting innovation. This is especially evident in agriculture, as small and medium farmers will not be able to access key land-based technologies such as soil carbon sequestration and remote soil carbon sensing equipment without adequate government support. ${ }^{16}$ (vi) In England, the lack of mandated food waste processing has thus far been a key barrier to abating emissions from the agricultural sector, although food-waste processing will be over-hauled by new legislation requiring food waste to be collected separately from $2023^{17}$. (ix) Continued regional inequality in the UK, while not strictly a barrier, has led to lower investment in certain areas, resulting in substantial untapped potential for economic growth and will be a challenge to address ${ }^{18}$.

\section{1.c Development compatible greenhouse gas emissions (GHGs)}

\section{1.c.i Country's current GHG emissions profile}

- Territorial Emissions (2019) ${ }^{19}: 370 \mathrm{MtCO}_{2}$, of which $170 \mathrm{Mt}$ from Oil, 161 from Gas, $27 \mathrm{Mt}$ from Coal, $4.4 \mathrm{Mt}$ from Cement ${ }^{20}$, and $4.6 \mathrm{Mt}$ from gas flaring ${ }^{21}$

- Consumption Emissions (2018): $540 \mathrm{MtCO}_{2}{ }^{22}$

- Emissions per GDP23: $0.1 \mathrm{kgCO}_{2} / \mathrm{GDP}$ (Territorial, 2018); 0.2 kgCO2/GDP (Consumption, 2018) 
- Emissions per capita: $5.7 \mathrm{tCO}_{2} /$ person (Territorial, 2018); $8.0 \mathrm{tCO} /$ person (Consumption, 2018)

The UK's annual $\mathrm{CO}_{2}$ emissions from fossil fuels and cement production (not including land use changes) have declined from their peak in 1971 at 660.39 Mt to $370 \mathrm{Mt}$ by 2019.24 The major factor in this decline is the reduction in coal use since 1955, oil since 1973 , and more recently, gas since 2004 and the recent growth of renewable energy in the UK. In 2019, UK CO 2 emissions accounted for $1.01 \%$ of annual global emissions, having declined from $7.76 \%$ of annual emissions in 1955 at its peak use of coal and concomitant with the growth of other countries' emissions over the intervening period.

\section{1.c.ii Sector-specific GHG emissions from the sectors which are key for development in this country}

In 2016, the UK's largest greenhouse gas emitting sector (carbon-dioxide equivalent, $\mathrm{CO}_{2} \mathrm{e}$ or $\mathrm{GHGe}$ ) was electricity and heat, totalling 125.2 Mt GHGe, followed by transport (120.5 Mt), buildings (84.7 Mt), agriculture (51.04 Mt), aviation and shipping (41 Mt), manufacturing and construction (36.4 Mt), industry (21.52 Mt), waste (18.16 Mt), other fuel consumption (9.48 Mt), fugitive emissions (7.42 Mt), and land use changes and forestry $(-12.77 \mathrm{Mt})^{25}$.

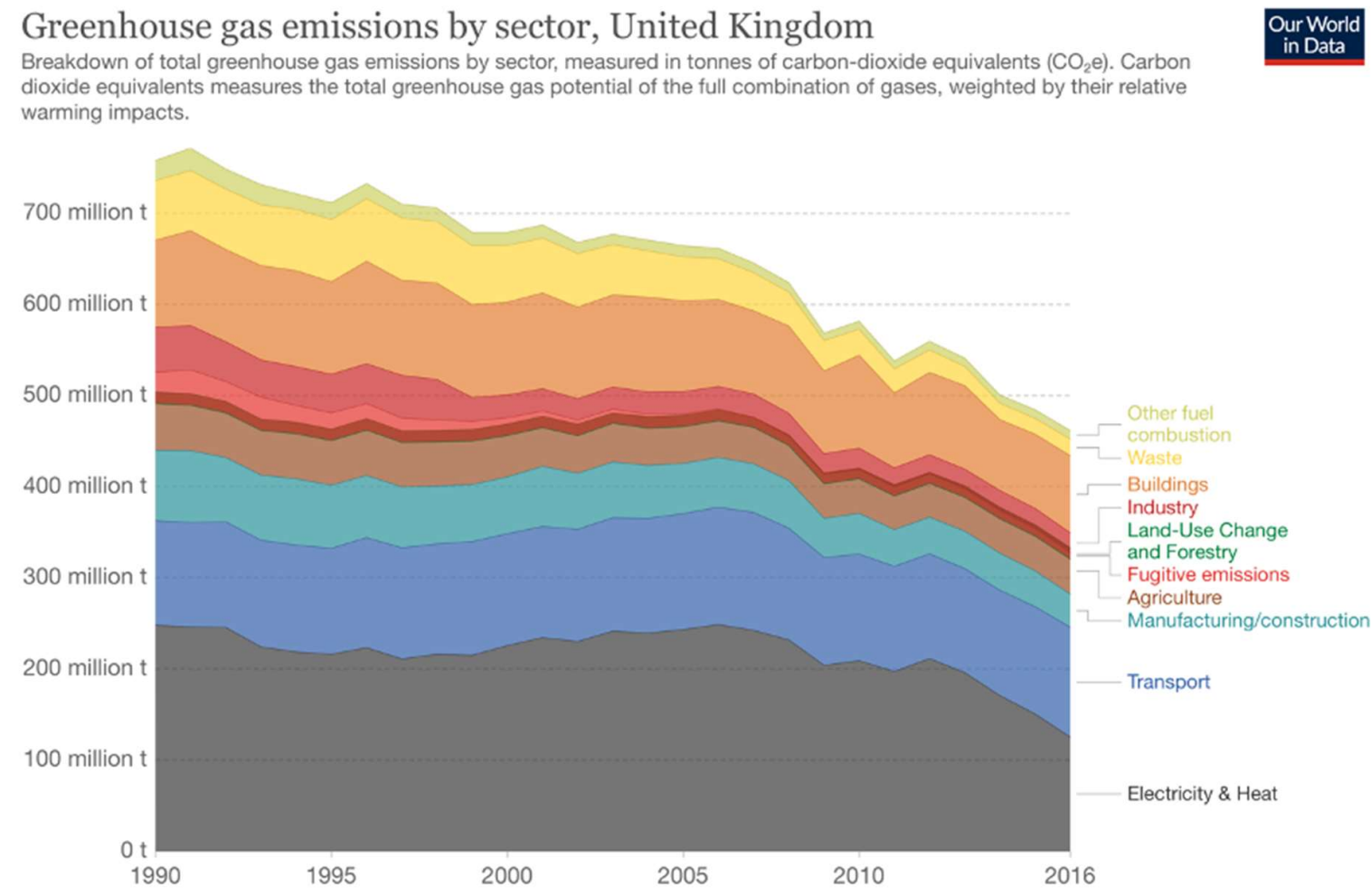

Figure 4: Greenhouse gas emissions by sector, UK (1990-2016). Our World in Data. Link 
Reductions in domestic emissions could in part be due to the UK economy further moving from a manufacturing to a service based economy, thereby increasing the dependence on imports and their associated embedded emissions ${ }^{26}$.

\section{Physical climate change - risks, adaptation, and opportunities}

\section{2.a Physical climate risk profile}

\section{2.a.i Physical climate risks that the country is already facing.}

Over the past 70 years, the UK has faced natural hazards primarily from storms, floods, and extreme temperature. Of these, storms and floods have so far inflicted the greatest financial losses while extreme heat and cold have inflicted the greatest number of casualties. ${ }^{27}$.

In particular, the North Sea Basin and eastern coast of Britain is prone to storm surges and coastal flooding. The western coast is particularly prone to hurricane force winds and extreme rainfall, although large storm events can take place throughout the UK. All major riverine areas of the UK may be prone to fluvial flooding, and urban and developed areas are most prone to pluvial or run-off flooding. The UK has also faced wildfires with growing frequency in recent years ${ }^{28}$.

According to the most recent UK Climate Change Risk Assessment (UKCCRA) from $2021^{29}$, the eight highest priority risks requiring urgent action are (i) risks to the viability and diversity of terrestrial and freshwater habitats from multiple hazards, (ii) risks to soil health from increased flooding and drought, (iii) risks to natural carbon storage areas and sequestration from multiple hazards leading to increased emissions, (iv) risks to crops, livestock, and commercial trees from multiple hazards, (v) risks to supply of food, goods, and vital services from climate-related collapse of supply chains, (vi) risks to people and the economy from climate-related failure of the power system, (vii) risks to human health, well-being, and productivity from heat exposure in homes and other buildings, and (viii) multiple risks to the UK from climate change impacts overseas, including supply chains and the financial sector.

In addition to these priority areas for action, the UK faces challenges from flooding in a range of important areas including critical infrastructure and housing as well as the risk of extreme heatwaves. Most recently, areas of the UK flooded in both summer and winter of 2020 , and winter of 2021 . In July 2019 , the highest temperature ever recorded in the UK occurred in Cambridge when air temperatures reached $38.7^{\circ} \mathrm{C}^{29}$. UK housing stock is not built to mitigate such temperatures. In England $25 \%$ of houses are at risk of overheating.

Across Northern Europe more widely, evidence points towards high increases in precipitation, and based on the most extended river flow database spanning the period 1960-2010, an increase in flood frequency in Northwestern Europe has been detected. Additionally, compound flooding is observed in Europe, including the UK, due to the 
combination of extreme sea level events and extreme precipitation events associated with high level of runoff 30 .

\section{2.a.ii How these risks are likely to change by 2050 due to climate change?}

Overall, it is estimated that the percentage of high magnitude risks (those that will have the greatest impact) the UK faces would increase from $26 \%$ in the present-day to $51 \%$ by 2050 in a $2^{\circ}$ scenario and $57 \%$ in a $4^{\circ}$ scenario ${ }^{31}$.

By 2050 , the UK will face increased risk from flooding and extreme heat. It is projected that the UK will experience an additional warming of $0.6^{\circ} \mathrm{C}$, resulting in a $10 \%$ increase in extreme precipitation events and up to a $50 \%$ chance each summer experiencing heatwaves as hot as in 2018/201932. Additionally, the UK could be at elevated risk of shortages in public water supply, with additional impacts for agriculture, industry, and energy generation (in plants requiring cooling water) ${ }^{33}$. Even low-population growth and moderate climate change scenarios suggest severe water shortages.

Furthermore, future climate in the UK could be expected to damage natural capital including freshwater, marine, and terrestrial ecosystems, soils, and biodiversity. These risks and others abroad could also impact both domestic and international food production and trade.

Relative sea level rise is extremely likely to continue in the oceans around Europe. ${ }^{34}$ Sea level could rise in the UK by between $10-30 \mathrm{~cm}$ above the 1981-2000 baseline by midcentury. ${ }^{35}$ These risks could still be present in a world in which warming had been limited to below well-below $2^{\circ} \mathrm{C}$. This should highlight the fact that meeting our net-zero target does not mean we can safely avoid adaptation measures.

Perhaps the largest climate-related risk facing the UK relates to failure to take adaptation seriously within the next couple of years ${ }^{36}$. By not immediately focusing on building resilience into vital eco-systems, the UK may never reach its net-zero target as damaged soils, wetlands, and peatlands begin to emit greater and greater amounts of greenhouse gases into the atmosphere.

\section{2.a.iii What additional long term climate risks might be incurred before $2100^{37} 38$ 39?}

It is estimated that, overall, the percentage of high magnitude risks the UK faces would increase from $26 \%$ in the present-day to $64 \%$ by 2080 in a $2^{\circ} \mathrm{C}$ scenario and $79 \%$ in a $4^{\circ}$ scenario.

Future climate risks are strongly dependent upon global emissions pathways. In a world in which future warming had been limited to well-below $2^{\circ} \mathrm{C}$ by 2100 , the UK could expect moderate risks to the state of global ecosystems and the economy, which could potentially impact domestic and international food production and trade. While there would still be an increase in heat-related deaths in the absence of adaptation, the UK would experience less extreme winter cold, resulting in opportunities for an increase in outdoor activities in winter and fewer cold-related deaths. However, there would still be a risk of up to $25 \%$ loss of blanket bog habitats and their potential to capture and sequester carbon-dioxide from the atmosphere. Water demand could also be expected to be greater 
than supply in up to $5 \%$ of catchments areas across the UK. Sea-level could rise by as much as $67 \mathrm{~cm}$ above the 1981-2000 baseline by 2100 .

Beyond $2^{\circ}$, these risks become much worse. In particularly severe scenarios (above $4^{\circ}$ warming), up to $70 \%$ of agricultural land could be classed as poor, and around $25 \%$ of the UK could face water deficits. Heat-related fatalities could range from 3,000 to 13,000 beyond the $2050 \mathrm{~s}^{40}$, and by the 2080 s flood damages could exceed $£ 4.5$ billion annually ${ }^{41}$.

Flood adaptation potential could also be exceeded in this scenario, leaving little choice but to abandon swathes of the UK, with $70-160 \%$ (based on current levels) more hospitals, roads, and railways at significant risk of flooding ${ }^{33}$.

Sea-level could rise by more than $1 \mathrm{~m}$ above the 1981-2000 baseline by 2100 and would continue to rise thereafter. In the sections below, the ways in which these physical factors translate into socioeconomic concerns are explored in more detail.

2.a.iii How might different physical, sociological and economic risks and vulnerabilities interact? (correlated and cascading risks, multiple interacting risks, interconnectivity between these different physical climate risks) 4243

All climate risks and opportunities in the UK interact to a greater or lesser extent, directly or indirectly. However, there have been few studies on interacting or cascading risks, and the latest UK climate risk assessment from 2021 considers these risks in more detail than ever before. Due to the connections between all infrastructure sectors, vulnerabilities in one network can cause disruption for others, potentially impacting the economy, wellbeing, and health. The UK's power network is particularly vulnerable, and all major hazards could trigger a cascade effect from the failure of the power sector to other sectors. By 2050, when the UK aims to have electrified many systems now reliant on fossil fuel energy, such as transportation and home heating, this could be particularly impactful; if the UKs power network does not work, the UK will not work.

Additional impacts should also be considered: food security may be impacted by negative impacts on agriculture, fisheries, and pollination through a combination of climate and non-climate risks both in the UK and abroad. A drop in international food production could spur growth in the UK agriculture sector, leading to increased risk for water scarcity, biodiversity, and other natural capital including soils. Negative effects on the provision of clean water (e.g. run-off from floods, low-river flows, and poor soil management) and natural flood alleviation may impact water security through a variety of means which may in turn imperil aspects of natural capital including biodiversity. Additionally, there are complex interdependencies between different forms of physical (e.g. transportation and energy networks) and social infrastructure (e.g. emergency services, health, and social care) and cascading risks exist where imperilling one strand of infrastructure could impact many others. Wellbeing and economic prosperity could be threatened by all these changes.

\section{2.b Sectoral and socioeconomic impacts of physical climate risks}




\section{2.b.i Economic sectors which are most exposed/vulnerable to physical climate risks.}

Businesses located or operating in coastal areas face the additional risk of losing coastal business locations or access to assets and facilities because of coastal erosion or flooding. Reduced water availability will impact on water-intense industries and have implications for other sectors across their supply chains. Through their international supply chains, distribution networks and global markets, UK businesses are exposed to extreme weather risks from around the world. These may include agriculture \& food manufacturing, automotive manufacturing. ${ }^{44}$ Risks and opportunities relating to adaptation goods and services have been identified, including for the following sectors: engineering and consulting, tourism, insurance and other finance products, and agriculture and food. ${ }^{45}$ Sectors such as finance, food, and utilities, are expected to face increased indirect risks from regulatory responses.

\section{2.b.ii Examples of how these sectors may be impacted by climate change including any material impacts on trade flows.}

There are several ways individual sectors and trade flows could be impacted by climate change, though all sectors may be impacted by climate risks related to interdependencies in infrastructure, site-specific risks including flooding, and impacts to productivity from adverse weather such as overheating. (i) In particular, the agricultural sector could be impacted, with effects on imports of food expected. International climate disruption and reduced food imports could spur growth in the UK agricultural sector, impacting biodiversity, soil quality, and other natural capital ${ }^{46}$. (ii) Difficulties in securing finance and insurance could impact a range of businesses and industry in multiple sectors. (iii) Tourism could be hit by climate related disruptions and changes in demand within the aviation/transport sector. (iv) Coastal businesses, industry, power generation, and ports could be particularly impacted by severe weather and sea level change, with crosssectoral impacts ${ }^{47}$.

\section{2.b.iii Demographic and ethnographic groups most at risk from climatic changes.}

Certain risks can impact certain communities to a greater degree. As noted by the UKCCRA, "Low-income households are particularly susceptible to climate change impacts" 48 . There is some evidence that more deprived communities are more likely to be found in areas with greater flood risk ${ }^{49,50}$. Additionally, because commodities such as food and household energy are responsive to climate impacts, and lower-income households spend a much greater proportion of their income on these, these households will have a much lower capability to prepare for or respond to future climate risk ${ }^{51}$. Furthermore, purchasing insurance may be prohibitively expensive for some households because of lower incomes but also because of the likelihood of living in areas with a greater risk of flooding52; this could lead to areas becoming effectively uninsurable. Because climate risks are not spread evenly around the UK and because areas with higher levels of deprivation are also not spread evenly, climate risk in the UK will disproportionately affect some geographic communities to a far greater degree than others.

Additionally, different types of households will have various levels of exposure to the netzero transition. For example, in general higher-income households consume more carbon 
in absolute terms, but lower-income households tend to consume more carbon relative to their income, and households in Northern Ireland tend to have larger carbon footprints due to a higher prevalence of oil-heated housing. Households are also exposed to the transition through the labour market, with people in certain occupations (skilled trade, and process plant and machine workers) more likely to work in more carbon-intensive industries. People in these occupations are also disproportionately likely to have a lower level of education and to be lower income workers. ${ }^{53}$ Analysis of households' exposure to the transition does not show where the costs will fall. This will depend on a range of factors, including the cost of decarbonising each sector, the availability of alternative lowcarbon products and the distribution of new green jobs in the economy. However, there are substantial opportunities for skills training. ${ }^{54}$

While few public policy studies in the UK have focused on the nexus between climate change and gender ${ }^{55}$, there are some public-health studies indicating that the effects of climate change may disproportionately affects women's health ${ }^{56}$. These include UK studies that indicated women were more likely than men to experience mental health problems following severe flooding $57,58,59$ and that European women were at higher risk of death in severe heatwaves than European men ${ }^{60}$.

\section{2.b.iv Broader risks to sustainable development within the country/region that arise from physical climate change.}

Risks to financial stability: Carbon-intensive businesses are expected to present increased credit risks for lenders, leading to a reduced availability and increased cost of capital for fossil fuel projects and activities in the coming years. ${ }^{61,62}$

\section{2.c Adaptation: Solutions \& Opportunities}

\section{2.c.i Country specific adaptation and resilience priorities against anticipated levels of climate change impacts.}

Priorities for adaptation in response to the risks highlighted in the CCRA are set out at the national level in the National Adaptation Programme (NAP) ${ }^{63}$, associated policy papers, and plans such as the 25 Year Environmental Plan (25YEP) ${ }^{64}$. Climate adaptation is a devolved matter, and Scotland ${ }^{65}$, North Ireland ${ }^{66}$, and Wales ${ }^{67}$ each have their own adaptation programmes and priorities.

Each of these programmes and plans sets out high-level priorities and more detailed actions to be taken across a range of relevant sectors and addressing the areas of risk as outlined in the CCRA. The priority areas addressed in the NAP include (i) improving the evidence base for future climate risk, (ii) building ecological resilience on land and in rivers and lakes, (iii) reducing pressures from spreading diseases by non-native invasive species, (iv) addressing water availability and quality, (v) implementing natural flood management and protection of coastal habitats, (vi) protecting soils and natural carbon stores, (vii) tackling challenges to forestry and agriculture, (viii) addressing future risks including flooding and overheating to infrastructure including energy, telecommunications, and transport, (ix) ensuring a cross-sectoral approach to infrastructure, $\mathbf{( x )}$ promoting a healthy, equitable, and resilient population by confronting challenges with planning, flood risk and erosion, water supplies and resources, 
overheating in buildings, delivery of health and social care, (xi) preparing businesses and industry for climate change by addressing losses in productivity, challenges to supplylines and access to capital, and (xii) enabling local government to plan for and implement climate change adaptation.

\section{2.c.ii Current/future solutions which have the potential to satisfy this country's adaptation needs.}

The UK's current list of adaptation solutions involves the wider participation of numerous stakeholders including DEFRA, the Environment Agency, Natural England, the Forestry Commission, the Marine Management Organisation, the Foreign and Commonwealth Office, the NHS, BEIS, and a wide range of other local and national governmental bodies. ${ }^{68}$ In devolved administrations these organizations differ and examples that follow have been pulled specifically from the NAP.

Although adaptation planning and reporting is still at an early phase ${ }^{69}$, the following are adaptation solutions highlighted as vital for the UK by the most recent UKCCRA (2021).

Natural environment \& capital: expanding evidence base on risks to natural capital; protecting more sites and improving existing sites and other areas of importance to biodiversity; restoring degraded ecosystems; contributing to wider goal of restoring or creating 50,000 ha of habitat; taking action for particular species/ecosystems most at risk; improving protection for important marine areas; ensuring extensive, healthy marine ecosystems; recovering fishing stocks; managing existing plant/animal diseases, lowering risk of new entrants; tackling invasive species; reforming water abstraction; improving quality and reversing deterioration of groundwater; expanding and improving natural flooding solutions; improving soil management and health; by 2030 , ensuring all soils are managed sustainably; restoring and protecting peatlands; enhancing resilience of and expand woodland resource; embedding adaptation within forestry; and introducing new environmental land management system for agriculture to deliver environmental benefits.

Infrastructure: building further understanding of infrastructure interdependencies; increasing resilience of transportation networks to flooding; increasing resilience of transportation networks to erosion and embankment failure; completing national database of essential bridges; increasing the resilience of telecommunications to flooding; and enhancing arrangements for data sharing between infrastructure operations both nationally and locally.

People and the Built Environment: embedding environmental net-gain in all new development; manage flooding and coastal erosion through defences and natural flooding solutions; enabling households and businesses to increase resilience to flooding; protect water resources for future generations; developing a culture of water responsibility; delivering more local green infrastructure; adapting health systems to protect against climate by enhancing monitoring and recording of flooding and heat and seeking best practice; protecting people from heat and cold; and ensuring that emergency services are prepared for extreme weather. 
Business and industry: increasing understanding of impacts to productivity; encourage resilient food supply chain; and increasing understanding of future changes in capital.

Local government: Planning for and implementing climate change preparedness at local level; embed adaptation into activities undertaken by local government; and ensuring adaptation is implemented at city level.

\section{2.c.iv Locally specific emerging sectors that might be of future importance for adaptation}

Here we consider examples of exciting initiatives or data that point to emerging solutions, including sectors or trends that are currently too small to notice, but may be relevant to future transitions. Some examples include: the use of trees for urban cooling, rewilding as a form of Nature-based Solution, to improve both biodiversity as well as carbon sequestration, and certain high-tech agricultural innovations, e.g. the use of precision farming or drones and robotics to adapt to new pressures on crops.

\section{Development compatible transition - risks, mitigation, and opportunities}

\section{3.a. Socioeconomic and sustainable development risks of a net zero transition}

3.a.i How different demographic and ethnographic groups would be impacted by a net zero transition

Regions, such as Yorkshire, the North East, and South Wales that depend on heavy industry for a large share of income could benefit from investment in sustainable, mitigation-compliant infrastructure, which requires management under a harmonised, comprehensive framework. ${ }^{70}$

Farmers and agricultural producers are likely to be directly affected because of largescale land use changes required for energy transition. This raises challenges and opportunities to accrue incomes from new revenue streams (e.g. soil carbon sequestration removes $\mathrm{CO}_{2}$ from the atmosphere while increasing productivity of soils). Without significant additional resource, small and medium farms are unlikely to be able to access the necessary training, machinery, and inputs for deploying transition-compliant practices. Planning and cooperation could help identify sectoral interests that are likely to be affected. ${ }^{71}$ There are also challenges relating to land rights and regulation as people who reside or work in areas that are required for hosting land-based transition projects could be affected. ${ }^{72}$

In terms of transport and travel, innovative technologies may bring about changes in congestion and volume of travel, patterns of consumption, quality of life and health, the nature of work, how communities develop, how peoples' mobility needs are met, how goods are delivered, and how businesses operate and organise in the future. ${ }^{73}$

\section{3.a.ii Risks to broader sustainable development within the country/region that could arise}


There are important trade-offs involved with all transition options - both among themselves as different paths to energy transition compete for limited financial, geophysical, and infrastructural resources - and more broadly as some large-scale transition options stand to compromise certain aspects of sustainable development and, counterintuitively, mitigation. ${ }^{74}$ In particular, large scale deployment of some GGR technologies are likely to compete with other priorities for the same resources. For example, large-scale Bioenergy with Carbon Capture and Storage (BECCS) and forestation are expected to put major pressure on land, water, and fertiliser resources, which would be needed in significant volumes to enable biomass production. ${ }^{75}$ On a global scale, these resource scarcities could result in rising world food prices and increased social inequality. ${ }^{76}$

Sectors that choose to invest in overseas initiatives such as forestation projects to offset emissions may need to consider the long-term sustainability implications of such ventures, especially if they involve an extraterritorial element and hosting in countries with ambiguous land rights. Previous forestation projects under the REDD+ and Clean Development Mechanism, for instance, have shown that benefits often do not reach host communities and result in dispossession of livelihoods for marginal communities, resulting in fierce local opposition to subsequent projects. ${ }^{77}$ Such concerns may be more pertinent to UK-based stakeholders given increasing public awareness and transparency surrounding mitigation initiatives.

Carbon pricing could also be a powerful tool for lowering emissions, however pricing should not negatively impact vulnerable communities such as those who are fuel poor ${ }^{78}$.

\section{3.b Just Transition}

\section{3.b.i What are the priorities for enabling a just transition in this country?}

As well as supporting high carbon industries to transition, a just transition would also support communities and labour forces to transition. Communities which currently have high levels of employment in oil and gas, mining and steel sectors could be the focus of an effort to attract new clean green industry investments and jobs with packages to support re-training and development. In financial services, (re)training may be required for the one million financial professionals in the UK, to ensure all financial professionals are aware of UK legislated targets and are taking steps to build climate into their operational decisions. ${ }^{79}$

Enabling a just transition relies on engaging with stakeholders, members of the public and local communities who are likely to be most directly affected, from the early planning stages through to long-term monitoring and revision of regulatory frameworks to ensure that local needs continue to be addressed. 80

There is a cross-party consensus that energy transition, particularly in the post-COVID19 recovery period, needs to deliver local and broader benefits. ${ }^{81}$ Local investment in infrastructure, particularly housing and transport, and green job creation are key 
strategies facilitating this and ensuring that transition alleviates rather than exacerbates socio-economic inequality. ${ }^{82}$

A key aspect of just transition is alleviating socio-economic disparity between socioeconomic groups and regions of the UK, as well as contributing towards a fairer global order. ${ }^{83}$ Levelling-up involves ensuring that people feel they can reach their full potential and lead good quality lives in their own communities, which may require investment in job creation, skills, education, health care, access to services and, where necessary, devolving certain powers to local governments to help regenerate struggling cities and towns. ${ }^{84,85}$

Another aspect of just transition means ensuring that the chosen projects/ options for facilitating transition are socially acceptable to the host community and broader public. ${ }^{86}$ Ensuring that the project planning and decision-making process adhere to principles of procedural justice are often regarded as core tenets of just transition. ${ }^{87}$

\section{3.b.ii What are some examples of future opportunities that could enable a just transition in this country, including adaptation to transition risks?}

Creating opportunities for local stakeholder and community and broader national public representation in the decision-making process are crucial for ensuring that these concerns are addressed and deemed socially viable, which could reduce the chances of opposition against projects further on in the transition stages. For example, it is well documented that the British public is more willing to accept energy transition costs if transition is perceived to be just. ${ }^{88}$ Recent polling studies suggest that public desire to engage with green recovery initiatives has increased significantly post-COVID-19, with $79 \%$ of the UK public feeling that economic recovery post-COVID should be aligned with net zero. ${ }^{89}$ To this end, a number of just transition movements are emerging both across the country and internationally (e.g. The Just Transition Centre established by the International Trade Confederation in 2016 and the Scottish Just Transition Commission established in 2019).90 The UK Government has initiated various citizens juries to facilitate fair representation of local communities and marginalised voices in the early planning stages of transition in the country. ${ }^{91}$ The All Party Parliamentary Group on the New Deal, for example, recruited people from diverse backgrounds including black and minority ethnic communities from across the country to understand what publics wanted to see in pursuit of a fairer, greener future.

Some communities (in collaboration with local councils) have taken the lead on smallscale transition initiatives, which have tended to excel in eliciting local support and delivering benefits to the host community. For example, the Nottingham Energiesprong project, which involved installing pilot retrofits to improve energy efficiency in homes, has resulted in tangible benefits such as increasing house prices and safer homes for homeowners. Decentralised renewable energy generation technologies (particularly solar energy) create new opportunities for energy consumers to produce for themselves and to complement the grid when needed. These local-based options are perceived as just and democratic, not least because they offer the possibility of additional revenue streams and democratise energy ownership and access, providing tangible benefits for local 
prosumers. ${ }^{92}$ Such options are at the intersection of the buildings and energy sectors and would require comprehensive coordination between sectors and national and local government institutions. ${ }^{93}$

The Government could increase incentives available to private stakeholders in key (highcarbon) sectors for investing in employees' green skills development and enhancing the quality of green jobs. Green skills development and job prospects could be cultivated by incorporating green skills education in schools and creating apprenticeships in transition related areas. ${ }^{94}$

\section{3.c Sectoral and socioeconomic impacts of a development compatible transition under each of the following transition pathways}

\section{- Steady, orderly, persistent transition pathway}

In addition to committing to achieving Net Zero emissions by 2050 , the UK Government has recently committed to a $78 \%$ reduction in emissions by 2035 , compared to 1990 levels, and incorporated the UK's share of international aviation and shipping emissions for the first time. ${ }^{95}$ This follows the recommendations as set out by the Climate Change Committee (CCC) in the $6^{\text {th }}$ Carbon Budget. ${ }^{96}$ The transition to Net Zero will impact all sectors of the UK economy, and require all sectors to participate in the required emissions reductions. The CCC's "Balanced Net Zero Pathway" sets out how sectoral emissions from each of the sectors shown in Figure 5 need to change up to 2050 for a steady, orderly, and persistent transition pathway to Net Zero, in line with the $6^{\text {th }}$ Carbon Budget commitments. 


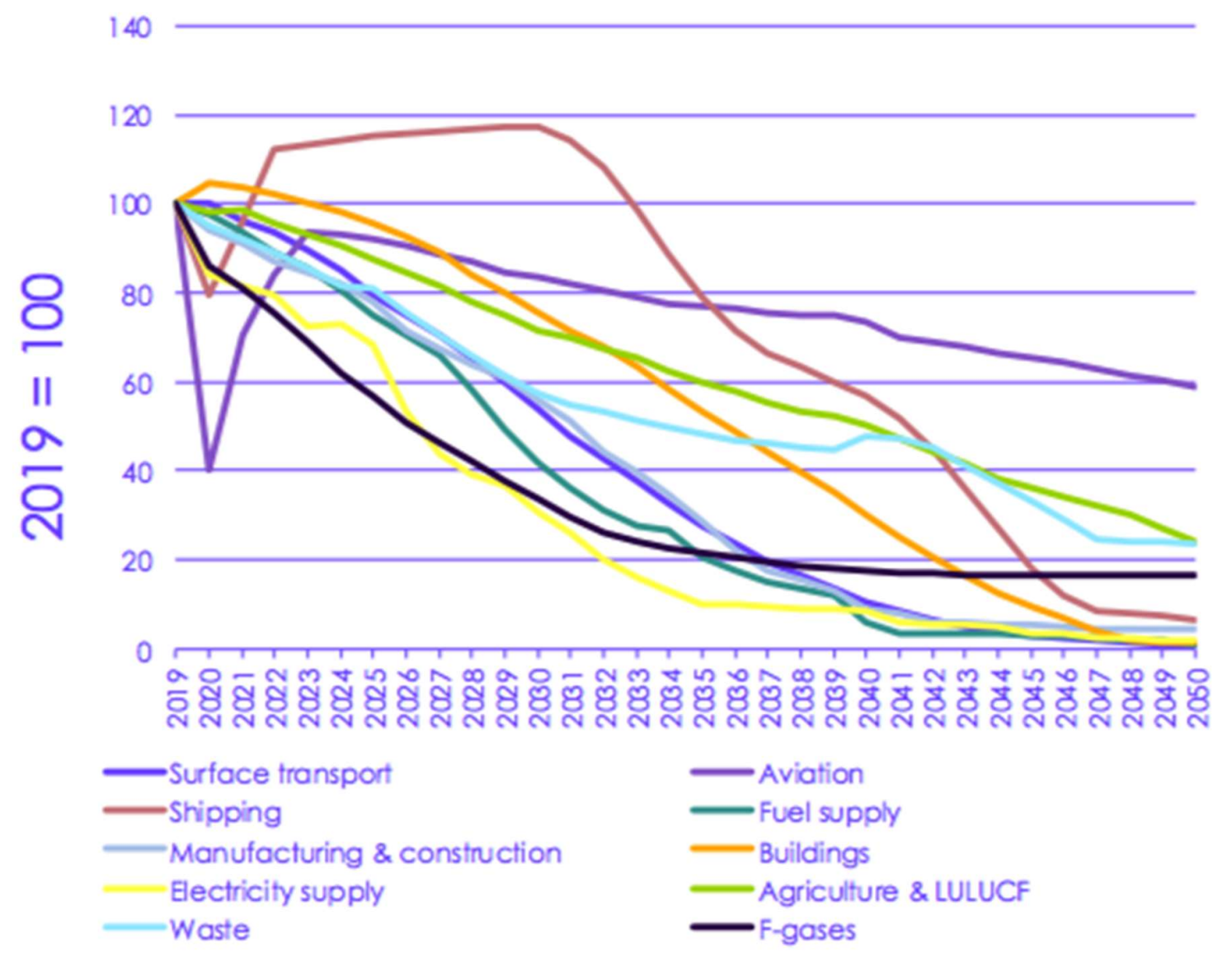

Source: CCC analysis.

Notes: Aviation and shipping pathways are lower in 2020 due to COVID-19. LULUCF = Land-use, land-use change and forestry.

Figure 5: Change in sectoral emissions in the balanced Net Zero pathway compared to 1990 levels. Committee on Climate Change, Sixth Carbon Budget, December 2020.

\section{- Late, disorderly transition pathway}

In general, a disorderly transition is a risk to stakeholders in all sectors because latecomers might not develop the necessary adaptive capabilities (e.g. sustainable inputs, low-carbon transport systems and monitoring capabilities) for facilitating or adapting to the transition. ${ }^{97}$ Also, the absence of comprehensive regulatory frameworks for overseeing and monitoring transition is likely to increase uncertainty and challenges across the economy Insurance could be withdrawn or repriced, impacting those most at risk from the impacts of climate change. Furthermore, increased climate awareness and consumer expectations for private sector actors to reduce carbon footprints could reduce consumer confidence. In general economic impacts are far worse when the transition to Net Zero is delayed and has to be made suddenly. Output could contract and GDP fall resulting in job losses impacting both businesses and households ${ }^{98}$. 


\section{Sectoral Impacts}

For the remainder of Part 3 of this country profile, it will be split by sectors. These sectors were identified as priority sectors of key importance for the net zero transition in the UK, in consultation with the UK expert committee members. The priority sectors are: 1) Aviation; 2) Financial Services; 3) Greenhouse Gas Removals; 4) Buildings/Built Environment, 5) Energy/Electricity Generation, 6) Surface Transport; and 7) Agriculture and Land Use. For each of these sectors in turn, the following questions are answered:

3.c.i Sectors most likely to be impacted, including material impacts on tradeflows, and considering both risks and opportunities.

3.c.ii Examples of how these sectors may be impacted by a net zero transition, including any material impacts on trade flows.

\section{3.d Development compatible emissions: Solutions \& Opportunities}

3.d.i Current/future solutions that can enable development-compatible emissions reduction in this country (in line with the SDGs).

3.d.ii Locally specific emerging sectors that might be of future importance for development compatible mitigation.

3.e Likely co-benefits and trade-offs of the solutions and opportunities identified, including, where relevant, in the context of the Sustainable Development Goals?

\section{Aviation:}

(3.c.i) Climate change (e.g. changes in weather) and energy transition (route changes, transition to low-carbon fuels) are expected to pose major challenges to this sector. ${ }^{99}$ Lack of collaboration between key stakeholders (scientists, airports, airlines, and governments etc.) will leave aviation vulnerable, likely to incur higher operating costs, increased delays, and climate-induced resource scarcities, which are more likely in the late disorderly scenario. ${ }^{100}$

(3.c.ii) Aviation will be difficult to decarbonise, 101 and the required reduction in demand for international aviation to meet net zero goals will have a strong impact on the industry. The net zero transition will also have impacts on aviation infrastructure (e.g. airports, fuel systems, transport) because of aircraft re-design \& propulsion technology advancements. In addition, a switch to alternate energy sources (e.g. sustainable aviation fuels, hydrogen, electric) may also impact UK exports on aviation components such as turbines, fuel $\&$ jet engines. This could consequentially impact employment levels at key industry players if they are unable to pivot their business model \& strategy. Research and development synergies and opportunities between wind power technologies and the aviation sector have been observed throughout the development of the sector. ${ }^{102}$

(3.d.i) The UK is a world leader on aero-propulsion and there are opportunities associated with the decarbonisation of flight, but also considerable technical challenges. There are three potential solution pathways for decarbonisation, which are currently still in early 
exploratory stages and very speculative: battery-powered electric aircraft, hydrogen fuel powered aircraft, and use of sustainable aviation fuels (SAFs) in existing aircraft. ${ }^{103} 104105$ Electric aircraft have now obtained certification by the European Aviation Safety Authority ${ }^{106}$, but are limited in range by current technology. Hydrogen can provide an alternative fuel that, when burned with oxygen, produces zero emissions, but the space required for fuel tanks reduces payload and range. SAFs can be used in existing aircraft but have high production costs and there are issues with sustainable sourcing of feedstocks. All three pathways require further research and investment, and roadmaps are needed for fuel delivery, scale up, and infrastructure requirements. General design changes to the fuselage of aircrafts are also being explored, characterized by their lower fuel consumption.

Additionally, behavioural change by consumers could help with reducing GHG emissions in the aviation sector. Global tourism in particular may have accounted for up to $5 \%$ of global emissions prior to the COVID-19 pandemic ${ }^{107}$. However, researchers have identified a number of barriers including dismissal by consumers of alternative modes of transportation, reluctance to consider adapting travel plans for climate change reasons, and a belief among travellers that responsibility for emissions abatement lies with others including the government, other countries, or businesses ${ }^{108}$. More generally, lessons can be learnt from public health interventions associated with tobacco, alcohol and sugar to help shape effective strategies to change behaviour across populations to reduce consumption of products with high GHG emissions (including travel) to sustainable ones $^{109}$.

(3.d.ii) A hydrogen transition in the UK energy sector may provide an infrastructural headstart when efficient adoption of this fuel can be implemented in aircraft. The UK has been identified as having enormous potential here to annually deliver around $£ 929 \mathrm{~m}$ in gross value added and 6,500 jobs, and saving over 3.6 million tonnes of $\mathrm{CO}_{2}$ annually by 2038. ${ }^{110}$

(3.e) Some airlines are offering consumers an option to pay extra (over the ticket price) to offset emissions from flying by investing in forestation initiatives which are (at least marketed as) compatible with some core SDGs (such as improving socio-economic equality), but such initiatives alone are unlikely to deliver the volume of negative emissions needed to align aviation with net-zero. Some airlines and companies have invested in large-scale carbon capture and storage (CCS) technologies (DAC or BECCS) to offset emissions from aviation by removing $\mathrm{CO}_{2}$ from the atmosphere. ${ }^{111}$ Such options could reduce costs for end-users if designed optimally (e.g. locating DAC near renewable energy supplies), but could also end up releasing more $\mathrm{CO}_{2}$ upstream (depending on energy source used to power CCS) or downstream (e.g. if captured $\mathrm{CO}_{2}$ is used to produce synthetic fuels or inputs for other industries), thereby contradicting the mitigative goal of transition. ${ }^{112}$

\section{Financial services:}


(3.c.i) Transition risks could result in financial portfolio exposure to stranded assets in carbon-heavy industries. Financial institutions also face the reputational risk of greenwashing which could undermine consumer confidence in green finance. The risks of delaying action are far greater. A disorderly transition could undermine the stability of the financial system, increase uncertainty, and make financial regulation more difficult (e.g. threat of climate-induced financial risks could make such risks uninsurable). ${ }^{113}$

(3.c.ii) In order to align with the Paris Agreement, two thirds of the world's known fossil fuel reserves cannot be burned. This could devalue investments in fossil fuels. The move towards a greener economy could also impact the investment value of companies that produce cars, ships and planes, and energy intensive industries like steel and cement production. Transition risks are a relatively new category of risk. As companies disclose more information on climate change exposure, financial firms will be able to make more informed decisions. In addition, liability risks arise from people or businesses seeking compensation for losses they may have suffered from the physical or transition risks from climate change outlined above. Liability cases could also include people who have suffered from physical events making claims against polluting companies who they argue are, at least in part, responsible. ${ }^{114}$

(3.d.i) London is a global financial hub, and the UK has a significant role to play in redirection of capital towards low carbon technology and strengthened climate resilience. The UK is also a pre-eminent centre for global insurance, with the potential for innovative solutions to improve coverage for populations vulnerable to climate change. The Climate Financial Risk Forum, co-chaired by the FCA and the PRA, has set out three key issues impinging on financial regulation:115 (i) Do markets understand and value assets correctly? (ii) Are suitable climate-adapted assets and product structures available? (iii) Is advice to clients of the risk of borrowing / investing correct (within regulations)?; as well as recommendations for financial institutions, ${ }^{116}$ including but not limited to: (I) New investment vehicles: Enabling public and private finance to come together; (ii) Prudence for the boards of regulated financial institutions to publish a climate-related financial risk appetite and capital allocation statement; (iii) Physical climate risk/stranded asset risk built into valuations; and (iv) Reviewing capital relief treatment of long-dated green assets.

(3.d.ii) Specific examples of how some of these measures are beginning to manifest in the market include sustainable land bonds, green mortgages, and distributed ledger technology.

(3.e) Co-benefits of the changes in investment style in financial services are typically associated with better long-term returns. However, in terms of trade-offs, insurance products are likely to be associated with higher premiums. There is the potential for anticipated consequences in terms of the just transition.

\section{Greenhouse gas removals (GGR):}

(3.c.i) Despite the strong scientific, and increasingly, political consensus surrounding the need for large-scale deployment of GGRs to meet an ambitious temperature target, ${ }^{117}$ deployment is significantly lagging. In some sense, therefore, the sector has already been 
experiencing a late disorderly pathway, with important lack of agreement over the type, scale, location and desirability of employing different GGR technologies, and their appropriate role relative to other energy transition options (particularly mitigation). ${ }^{118}$ Potential GGR solutions include: Bioenergy with Carbon Capture and Storage (BECCS, Direct Air Capture of $\mathrm{CO}_{2}$ (DAC), the use of wood as a sustainable construction material, Nature-based Solutions ( $\mathrm{NbS}$ ), and other technologies including biochar and carbonnegative cement. These technologies typically require huge start-up investments (e.g. a full size BECCS demonstration plant). ${ }^{119}$

(3.c.ii) GGR is a crucial part of the UK's strategy to achieve its net zero target, but the required technologies are currently in their infancy ${ }^{120121}$. GGR technology applied to certain industries may become stranded assets as the transition progresses. There is a serious risk that as countries upscale GGRs, resource inputs needed to operate these technologies at climatically relevant scales will become scarce and expensive. ${ }^{122}$

(3.d.i) There are many opportunities associated with the development of GGR technologies. It has been estimated that the GGR technology value chain could have a cumulative value of between $£ 35.3$ and $£ 38.8$ billion by $2050 .{ }^{123}$ Surpluses of GGR technologies have the potential to become an asset that can be sold to other countries as a means of offsetting their emissions as they develop their own strategies towards NetZero. Despite sequestration requiring a long-term investment horizon, given the forecast increases in the price of carbon, if action is taken now it could be capitalised on later down the line. ${ }^{124}$ Storage-based accounting could be used instead of carbon taxation as a means of paying for GGR 125126127 , as could a 'carbon takeback obligation' (CTO) which obligates all primary extractors and importers of fossil carbon to demonstrate permanent sequestration of a progressively increasing fraction of $\mathrm{CO}_{2}$ generated by production, transport and use of their products. ${ }^{128}$ Restoring our natural systems could provide $37 \%$ of the $\mathrm{CO}_{2}$ mitigation needed by 2030 to meet the Paris Agreement 129130131 .

(3.d.ii) The UK can capitalise on its unique access to suitable reservoirs for CCS, as well as utilising its large engineering industry that has much of the relevant expertise required to establish substantial infrastructure for transport and storage of $\mathrm{CO}_{2}{ }^{132}$.

(3.e) The resource requirements associated with some GGR methods, including requirements for land, energy, and water, can place limits on the location and scale of their implementation and may lead to resource competition with other human activities, e.g. land use for agriculture and food production ${ }^{133}$. Conversely, there are also co-benefits associated with some GGR methods, e.g. enhanced crop productivity or mitigating biodiversity loss and flood risk through Nature-based Solutions, as well as potential benefits for well-being and health. There is potential for creation of new jobs associated with the research and installation required for GGR, as well as the possibility for capture of other pollutants, e.g. sulphur dioxide and particulate matter.

Most GGR solutions require some level of international collaboration to provide optimum mitigative outcomes. For example, inadequate biomass supply could drive the UK to further import biomass to power bioenergy and $\mathrm{CCS}^{134}$, as Drax already does, but this would raise new challenges relating to monitoring transboundary energy corridors and 
enforcing long-term agreements internationally. Resources diverted to supplying and running GGRs such as energy, land and water would reduce resources available for other priorities requiring the same resources, resulting in higher input prices and difficult political decisions over competing priorities.

\section{Buildings/built environment:}

(3.c.i) The built environment is responsible for $40 \%$ of UK GHG emissions (including direct and indirect emissions, embodied and operational) and thereby holds significant potential for contributing to the net zero transition. ${ }^{135} 136$ Key areas for change include reducing the use of raw materials, reduction in glazing areas to reduce heat loss and replacing gas boilers with alternatives such as air source heat pumps or hydrogencompatible boilers. ${ }^{137}$

(3.c.ii) The built environment is a difficult to decarbonise sector. More investment in low carbon and efficiency measures is required to retrofit old building stock. Behaviour change in domestic energy use will also be required to reduce energy consumption in buildings. Significant re-skilling is required, e.g., in the construction sector. Steel and concrete are hard-to-abate carbon-intensive building materials. Sustainable building design strategies include using timber as an alternative, which may impact the value of assets. ${ }^{138}$ In trade of building materials, in 2019, the UK exported \$1.2BN and imported $\$ 2.14 \mathrm{BN}$, of stone, plaster, cement or similar materials. Iron and steel-based import trade accounted for $\$ 16.8 \mathrm{BN}$ and $\$ 12.8 \mathrm{BN}$ of exports. Steel is an intensively traded product. The UK imports 6.6 million tonnes of steel each year, around $61 \%$ of requirements, and exports 3.5 million tonnes, around $48 \%$ of its production.

(3.d.i) Buildings and the built environment represent a large opportunity for mitigation of GHG emissions in the UK. The UK has an unusually old building stock and so retrofitting will play a key role in achieving net zero. Emissions reductions in buildings can be achieved in two ways: (i) By reducing energy usage in buildings through energy efficiency measures such as retrofitting, insulation, double glazing, energy efficient appliances, behaviour change and smart heating systems; and (ii) By ensuring that energy used in buildings is low or zero carbon, e.g. through use of heat pumps. New builds will need to meet extremely ambitious standards of energy efficiency, such as Passivhaus. Lifetime carbon of construction will need to be accounted for by replacing use of carbon intensive materials, such as concrete and steel, with sustainable alternatives like timber.

Potential solutions to enable decarbonisation of steel could be either 1) to finance the additional ongoing cost the steel sector and other heavy industry face in decarbonising, which raises questions about who and how the UK pays for the environmental subsidies required; or 2) to create a market for low-carbon steel, where UK steelmakers are not outcompeted by imported high-carbon, low-cost steel. The latter could require carbon border adjustments and product standards to create a market for low carbon steel. ${ }^{139}$ 
Changing to electric arc furnace systems would allow the UK to recycle its own steel, meaning operational costs would not increase. However, a challenge to this transition would be high capital costs ${ }^{140}$.

Approximately $5 \%$ of global human $\mathrm{CO}_{2}$ emissions currently arise from cement production. Consequently, there is commercial interest in developing low-carbon cements and related binders suitable for use 'at scale' in concrete production, such as alkali binders ${ }^{141}$. Operational improvements could also deliver up to $80 \%$ reduction in cement use without needing new cement chemistries.

(3.d.ii) Smart buildings with the ability to generate renewable energy could supply energy to both the building and the surrounding area, potentially complementing the energy sector when needed. ${ }^{142}$

(3.e) New cooling approaches can improve air quality and energy efficiency whilst decarbonising energy supply. More generally the transition to net zero in the built environment should also improve energy security, comfort and health whilst also providing regeneration benefits, especially for the fuel poor. Materials passports for construction materials could enhance circularity and reduce use of raw materials at the construction stage. ${ }^{143}$

\section{Energy/electricity generation:}

(3.c.i) The electricity sector has transitioned towards a greater share of renewable energy and now the major challenges relate to integrating these technologies with pre-existing infrastructure. Oil and gas sectors have maintained greater interest in the use of carbon capture and storage (primarily fossil) as a means to offset emissions through permanent storage, ${ }^{144}$ but coordination is needed to ensure that the portfolio of projects complement, rather than compete, with each other. GGR technology could play a significant role in reducing emissions within the energy sector but it requires investment and an appropriate regulatory framework. Energy firms that were to invest in BECCS or DAC could accrue additional revenues by selling captured carbon for utilisation in a range of other industries such as synthetic fuels, horticulture, carbonated drinks and, most prominently, enhanced oil recovery/ enhanced gas recovery (using the captured carbon to recover oil/ gas).

(3.c.ii) The fluctuations in renewable energy sources such as wind and solar will necessitate increased flexibility in energy demand, and development of flexible storage solutions to meet peak demand ${ }^{145}$. There is an opportunity for certain technologies to overcome the costs associated with some of the most promising (high-investment) options in this sector by providing additional revenue streams (e.g. bioenergy and CCS can provide an additional revenue stream by generating a pure $\mathrm{CO}_{2}$ stream). Direct air capture could offer location-independent sourcing of $\mathrm{CO}_{2}$, potentially offsetting CCS costs by significantly reducing transport and energy-input costs if DAC facilities are located proximate to renewable energy sources ${ }^{146}$. 
(3.d.i) Emissions from electricity generation in the UK have already fallen by $68 \%$ between 1990 and $2018^{147}$. This drop in emissions was driven by a reduction in electricity demand (12\% decline in residential electricity consumption from 2008 to 2018) and a reduction in carbon intensity of electricity generation (primarily driven by the phasing out of coal). Opportunities for further emissions reductions in this sector are split across 5 areas:

- Decarbonising power: The overall strategic approach is to decarbonise electricity production and then use low-carbon electricity as the primary power source for as much of the economy as possible, for example through surface transport (electric vehicles) and thermal control in buildings (heat pumps). It will also be important to foster energy efficiency through incentives like carbon pricing and regulatory measures like building standards.

- Variable renewables: The UK benefits from extensive wind and solar power resources (22\% of total UK energy generation in 2018) and the cost of these renewable energy sources has fallen significantly over the past decade. New offshore wind projects are now cheaper, in terms of levelised cost, than new gas projects for electricity generation, as seen by recent government awarded contracts ${ }^{148}$. Further expansion in offshore wind generation will be required by 2050 for Net Zero.

- Firm power: Nuclear power could play a role to provide predictable low-carbon power in a system driven by variable renewable sources, albeit at a higher cost than renewables. In particular, the potential of small modular reactors (SMRs) is an area of research investment. These small power stations could create low-cost, low-carbon electricity for up to 60 years. Each unit built produces 440 megawatt of electricity each hour, which is enough to power 450,000 homes and more than 62,000 electric cars. SMRs have lower capital costs because their smaller size means they can be manufactured in pre-tested modular sections in dedicated factories and assembled on site with greater efficiency and reduced construction times. ${ }^{149}$

- Dispatchable generation: Other low-carbon power sources will be required to provide dispatchable electricity generation at peak times to complement variable renewable generation. These sources could include gas with carbon capture and storage (CCS), bioenergy with CCS (BECCS) and hydrogen, nuclear, and hydroelectric power plants.

- Flexibility and storage: The nature of variable renewables means that they are dependent on the weather and cannot vary their output to meet periods of peak demand. This will require an increasingly flexible electricity system to offset the intermittency of renewable sources e.g., using innovative storage solutions (batteries, hydrogen, or pumped hydro) or shifts in demand.

(3.d.ii) Examples include: i) electric vehicle and/or heat pump owners could be incentivised to consume electricity outside periods of peak demand; ii) significant efforts are in progress for heat networks considering their potential towards achieving net zero targets, including district heat networks, reports on thermal storage technologies and associated policy and barriers. 150 
(3.e) The transition to renewable energy sources will improve air quality and reduce electricity prices ${ }^{151}{ }^{152}$. New industrial opportunities and jobs will be created thanks to investment in expansion of renewable energy generation, and development of the CCS and hydrogen markets. There will be opportunities to export engineering expertise, components, and services for the global offshore wind market. If DAC is combined with biomass, as in BECCS, it could provide additional revenue streams from $\mathrm{CO}_{2}$ generation.

\section{Surface Transport:}

(3.c.i) The transport sector makes up a large share of UK GHG emissions $(22 \%$ in 2019) ${ }^{153}$. Reducing demand for private car transport and encouraging a behavioural shift to alternative forms of (public) transport and active travel will be necessary to achieve net zero. Roll-out of electric vehicles (EVs) will require development of accessible charging infrastructure and enhancing battery storage.

(3.c.ii) There are challenges associated with EVs for low-income households and people in deprived areas who may not be able to afford EVs, and who have poor linkages to existing transit networks. For heavy goods vehicles (HGVs) and freight transport, decisions need to be made as to what the best approach is for decarbonisation, and trials carried out (either electrification through Electric Road System (ERS) ${ }^{154}$, or hydrogen fuel cells).

(3.d.i) Solutions and opportunities within the transport sector are focussed around i) a modal shift away from private car use to other forms of low or zero carbon transportation including public transport and active travel, and ii) phasing out the use of fossil fuels to power vehicles, primarily through electrification. A modal shift can be encouraged by producing dense, mixed use, and attractive low traffic neighbourhoods that prioritise walking and cycling ${ }^{155}$, and by incentivising alternatives to private car ownership (e.g. carpooling, car clubs, public transport). Encouraging coordination of home delivery services and removing barriers to electrification of urban delivery vehicles (including charging depots), can reduce duplication, traffic, and carbon emissions. Uptake of electric vehicles (EVs) can be encouraged by rolling out widespread public and private charging infrastructure and by creating low emissions zones in larger cities. This implementation of regulations banning internal combustion engine vehicles may also accelerate this shift. High-speed rail and land systems may offer alternatives to short-haul flights as shifting dynamics in technologies and demand change. There is an opportunity for the development of automation \& connectivity of land vehicles using AI, software, and sensors. Research indicates that connectivity can boost a vehicle's energy efficiency anywhere between five and 20 per cent. ${ }^{156}$ Furthermore, UK-based manufacturing of selected zero-emission and autonomous vehicle components could be worth $£ 16.8$ billion per year by 2030 and could sustain up to 80,000 jobs, but only with the right set of flexible policy measures, incentives, and regulation. ${ }^{157}$

.Encouraging behavioural change by promoting physical activity to replace short car trips may be particularly effective in decreasing private car use and offer several co-benefits including increased health and fitness. As with other types of behavioural change, 
convincing the public to shift their established routines can be very difficult ${ }^{158}$, but may be made easier in the case of transportation by providing structural enhancements such as creating safe, convenient, walking and cycling routes to local destinations and by coupling with communication, marketing, and policy enhancements to promote active transportation. ${ }^{159}$

(3.d.ii) Examples include: targeted deployment of transition technologies (commercialisation of bioNG/biodiesel around points of existing supply); operational and design efficiencies to reduce fleet emissions by using digitisation and analytics to improve usage at a company/sector level; joint heavy goods vehicle (HGV) purchasing commitments to increase demand whilst reducing unit price risk; scale up replacement of small and medium-sized buses/trucks in viable short range and urban duty-cycles using existing battery electric vehicles (BEVs) and fuel cell electric vehicles (FCEVs) solutions. Green finance for lending portfolios to support vehicles using alternative technologies and infrastructure purchases, particularly for small owners. ${ }^{160}$ Regions such as the West Midlands and Eastern Scotland are centres of zero emission and autonomous vehicle innovation. ${ }^{161}$

(3.e) Reduced demand for car travel will lead to lower levels of congestion and better air quality, as well as reducing the number of road-related injuries and fatalities. Switching to active forms of travel will improve health and wellbeing. Widespread uptake of EVs will improve air quality and reduce noise.

\section{Agriculture and land use:}

(3.c.i) This sector represents a large share of UK emissions (10\% in 2019) and will require fundamental changes in land use as part of the transition to net zero ${ }^{162}$. Significant land use changes are likely to be needed as the transition accelerates and pressure is placed on land use for multiple purposes ${ }^{163}{ }^{164}$. Landowners and farmers will also be impacted by a changing regulatory landscape that moves away from the countryside stewardship scheme to the 2020 Agriculture Act which embeds public money for public good 165166 . Agriculture may also experience a shift away from dairy and meat production in line with $6^{\text {th }}$ carbon budget meat reduction targets of $35 \%{ }^{167}$. Farmers may also need to reduce use of traditional fertilisers and shift to slow-release ones ${ }^{168} 169$.

(3.c.ii) Around $9 \%$ of current agricultural land may be required by 2035 for actions to reduce emissions and sequester carbon (afforestation, peatland restoration, bioenergy crops), rising to $21 \%$ by 2050 . This will require changes in agricultural practices (increased productivity) and diets, as well as re-skilling in the agricultural sector. Technology has the capability to optimise production to match demand and balance out the food-scarcity equation. Temperature and moisture sensors, devices, robots, aerial images, and GPS technology are just some of the innovations that may transform agriculture operations, making farms more environmentally friendly, more profitable, efficient, and safer ${ }^{170}$.

(3.d.i) The priority amongst UK farmers today is to use available inputs more effectively and efficiently. This is part of a broader shift towards a virtuous cycle of lower costs, more 
sustainable land use and - ultimately - greater productivity and profitability. Smart policy is required to realign food systems and integrate the 'true cost' of food, and to address the food inequality in the UK. The development of personalised health-care plans and apps should help people address diet problems and help them choose a healthy, sustainable, and nutritional diet; the more personalised this is the less waste should occur ${ }^{171}$. Solutions to sequester carbon need to be integrated effectively with other land use demands such as food production and could involve scaling up reforestation, afforestation, and natural forest management as well as enhancing soil carbon sequestration through low- and no-till agriculture, cover crops or crop rotations, and optimised grazing. Innovation like drones can support with scaling out reforestation as they can plant seeds via air. ${ }^{172}$ Regenerative agriculture practices would allow for an integrated approach to land use, optimising interactions between plants, animals and humans but leveraging nature-based solutions. They apply biodiverse and ecosystembased principles to create a sustainable food system. Research in Europe and the UK has found that small scale agroeconomic farms displayed positive productivity and financial viability. ${ }^{173}$

(3.d.ii) Emerging solutions in the agricultural sector include: vertical farming, the use of aeroponic greenhouses, and the use of robotics such as weeding robots. Development in this area will heavily rely on the investment in technologies such as drones, Al, loT and sensors that can create smart farms to constantly monitor and track conditions in farms. ${ }^{174}$ Cities can also play a significant role in sparking a shift to a fundamentally different food system in which we move beyond simply reducing avoidable food waste to designing out the concept of 'waste' altogether. As the place where most food eventually ends up, cities can ensure inevitable by-products are used at their highest value, transforming them into new products ranging from organic fertilisers and biomaterials to medicine and bioenergy. Rather than a destination for food, cities can become centres where food by-products are transformed into a broad array of valuable materials, driving new revenue streams in a thriving bioeconomy ${ }^{175}$.

Behavioural change among both consumers and farmers will also be important in future years, but as in other sectors, this presents challenges, particularly became for many, consumption of meat and dairy is a traditional social practice re-informed by economics and institutional factors including marketing ${ }^{176}$. As with other carbon-intensive products, reducing demand can be driven by lessons can be learnt from public health interventions associated with tobacco, alcohol and sugar to help shape effective strategies to change behaviour across populations to reduce consumption of products with high GHG emissions (including travel) to sustainable ones ${ }^{177}$.

(3.e) A transition in agriculture and land use can lead to a host of co-benefits. The ecosystem services provided by natural vegetation and functioning ecosystems range from improved air and water quality to flood risk alleviation and increased social and ecological resilience. Co-benefits for biodiversity when more land is given over to the conservation of biodiversity as well as carbon sequestration are also likely. The use of land for multiple purposes could also lead to more productive land-use. Additional cobenefits could include healthier diets resulting from changes in the crops that are grown. 
Finally, improved air and water quality, aligned with healthier diets could lead to improved health in the round.

\section{Definitions of key terms}

Mitigation The lessening of the potential adverse impacts of physical hazards through actions that reduce hazard, exposure, and vulnerability.

Adaptation The process of adjustment to actual or expected climate and its effects, in order to moderate harm or exploit beneficial opportunities.

Resilience The ability of a system and its component parts to anticipate, absorb, accommodate or re- cover from the effects of a hazardous event in a timely and efficient manner while retaining the same basic structure and ways of functioning, the capacity for self-organization and the capacity to adapt to stress and change.

Vulnerability The degree to which a system is susceptible to, or unable to cope with, adverse effects of climate change, including climate variability and extremes.

Risk The potential for consequences where something of value is at stake and where the outcome is uncertain, recognizing the diversity of values. Risk is often represented as probability or likelihood of occurrence of hazardous events or trends multiplied by the impacts if these events or trends occur.

\section{Acknowledgements}

This country profile was written by Dr Ethan Aines (Cambridge Zero, University of Cambridge, UK), Dr Zeynep Clulow (Energy Policy Research Group, University of Cambridge, UK) and Mr Alasdair Neilson (Department of Geography, University of Cambridge, UK) with input from in-country academic experts Dr Emily Shuckburgh (Cambridge Zero, University of Cambridge, UK), and Professor Steve Evans (Institute of Manufacturing, University of Cambridge, UK) in the context of the BEIS COP26 Futures We Want project. The production of the document was supported by project teams at Cambridge Zero (University of Cambridge) and Deloitte. The authors thank Dr James Pope at the Met Office and Dr Ryan Hogarth, Ricardo Energy and Environment, for their reviews which significantly improved the quality of this manuscript 


\section{References}

1 ONS (2021) Breakdown of contributions to UK economy by sector, Whole Economy (aggregated \& detailed breakdown) Chained Volume Measure GVA, https://www.ons.gov.uk/employmentandlabourmarket/peopleinwork/labourproductivity/d atasets/annualbreakdownofcontributionswholeeconomyandsectors

2 Nabarro, B. (2020) UK Economic Outlook, The Long Road to Recovery. Institute for Fiscal Studies. https://ifs.org.uk/uploads/CH2-IFS-Green-Budget-2020-UK-EconomicOutlook-.pdf

3 Hardt, L. et al. (2021) What structural change is needed for a post-growth economy: A framework of analysis and empirical evidence. Ecological Economics. https://doi.org/10.1016/j.ecolecon.2020.106845

4 Shuckburgh, E. et al. (2020). A Blueprint for a Green Future - Multidisciplinary report on a green recovery from COVID-19 by the Cambridge Zero Policy Forum. Cambridge Zero, University of Cambridge. https://www.cambridge.org/engage/coe/articledetails/5fa1b3a118fd43001231c78f

5 HM Treasury (2021) Build back better. Policy paper.

https://www.gov.uk/government/publications/build-back-better-our-plan-for-growth/buildback-better-our-plan-for-growth-html

6 The Committee on Climate Change (2017) UK business opportunities of moving to a low-carbon economy. https://www.theccc.org.uk/publication/uk-energy-prices-and-bills2017-report-supporting-research/

7 HM Revenue and Customs (2019) UK Overseas Trade in Goods Statistics Summary of 2019 Trade in Goods.

https://assets.publishing.service.gov.uk/government/uploads/system/uploads/attachmen t data/file/865366/OTS 2019 Annual Summary.pdf

8 The Committee on Climate Change (2017) UK business opportunities of moving to a low-carbon economy https://www.theccc.org.uk/publication/uk-energy-prices-and-bills2017-report-supporting-research/

9 United Nations Development Programme (2020) Human Development Reports, United Kingdom. http://hdr.undp.org/en/countries/profiles/GBR

10 Office of National Statistics (2020), Household income inequality, UK: financial year ending 2020 (provisional).

https://www.ons.gov.uk/peoplepopulationandcommunity/personalandhouseholdfinances lincomeandwealth/bulletins/householdincomeinequalityfinancial/financialyearending202 Oprovisional

11 Shuckburgh, E. et al. (2020). A Blueprint for a Green Future - Multidisciplinary report on a green recovery from COVID-19 by the Cambridge Zero Policy Forum. Cambridge Zero, University of Cambridge. https://www.cambridge.org/engage/coe/articledetails/5fa1b3a118fd43001231c78f 
12 The Committee on Climate Change (2017) UK business opportunities of moving to a low-carbon economy

https://www.theccc.org.uk/publication/uk-energy-prices-and-bills-2017-report-

supporting-research/

13 G. Nemet, et al. (2018) Negative Emissions. Environmental Research Letters.

https://iopscience.iop.org/article/10.1088/1748-9326/aabff4/meta

14 S. Fuss et al. (2014) Betting on negative emissions. Nature Climate Change.

https://www.nature.com/articles/nclimate2392?page=1

15 Committee on Climate Change (2019) UK Housing: Fit for the Future?

https://www.theccc.org.uk/wp-content/uploads/2019/02/UK-housing-Fit-for-the-futureCCC-2019.pdf

16 R. Lal (2020) The role of industry and the private sector in promoting the " 4 per 1000 " initiative and other negative emission technologies. Geoderma.

https://doi.org/10.1016/j.geoderma.2020.114613

17 DEFRA Press Office (2020) Household food waste to be collected separately by 2023 and 50,00 city trees to be planted in Urban Tree Challenge Fund.

https://deframedia.blog.gov.uk/2020/02/10/household-food-waste-to-be-collectedseparately-by-2023-and-50000-city-trees-to-be-planted-in-urban-tree-challenge-fund/

18 Bhattacharjee, A. et al. (2020) The prospects for regional disparities in the UK in times of Brexit and COVID-19. National Institute Economic Review.

https://doi.org/10.1017/nie.2020.25

19 Friedlingstein et al. (2020) The Global Carbon Budget 2020, Earth System Science Data.

https://doi.org/10.5194/essd-12-3269-2020

20 Andrew, R. M. (2019) Global CO2 emissions from cement production, 1928-2018. Earth System Science Data.

https://www.earth-syst-sci-data.net/11/1675/2019/

21 CDIAC: Gilfillan, D., Marland, G., Boden, T., and R. Andres (2019) Global, Regional, and National Fossil-Fuel CO2 Emissions. Carbon Dioxide Information Analysis Center at Appalachian State University, Boone North Carolina.

https://energy.appstate.edu/research/work-areas/cdiac-appstate

22 Friedlingstein et al. (2020) The Global Carbon Budget 2020, Earth System Science Data.

https://doi.org/10.5194/essd-12-3269-2020

23 IEA/OECD (2019) CO2 Emissions from Fuel Combustion Highlights. Paris.

Page 31 of 45 
https://webstore.iea.org/co2-emissions-from-fuel-combustion-2018-highlights

24 Friedlingstein et al. (2020) Global Carbon Project. Supplemental data of Global Carbon Budget 2020 (Version 1.0) [Data set].

https://doi.org/10.18160/gcp-2020

25 CAIT Climate Data Explorer (2021) Historical emissions data, greenhouse gas emissions measured in tonnes of carbon dioxide equivalents $\left(\mathrm{CO}_{2} \mathrm{e}\right)$, based on 100year global warming potential factors for non- $\mathrm{CO}_{2}$ gases.

https://www.climatewatchdata.org/data-explorer/historical-emissions?historicalemissions-data-sources=cait\&historical-emissions-gases=all-ghg\&historical-emissionsregions=All\%20Selected\&historical-emissions-sectors=total-including-lucf\&page=1

26 UK's Carbon Footprint 1997-2018, Department for Environment, Food and Rural Affairs.

https://assets.publishing.service.gov.uk/government/uploads/system/uploads/attachmen $\underline{\mathrm{t} \text { data/file/979588/Defra UK carbon footprint accessible rev2 final.pdf }}$

27 EM-DAT (2020) Natural hazards in the UK, 1952-2020. EM-DAT, CRED. UCLouvain, Brussels, Belgium.

http://www.emdat.be/

28 Stock, M.J., \& Wentworth, J. (2020) Evaluating UK natural hazards: the national risk assessment. UK Parliament POST.

https://doi.org/10.31223/osf.io/cz6st

29 Committee on Climate Change (2021) Independent Assessment of UK Climate Risk, https://www.theccc.org.uk/publication/independent-assessment-of-uk-climate-risk/

30 Ranasinghe, R., A. C. Ruane, R. Vautard, N. Arnell, E. Coppola, F. A. Cruz, S. Dessai, A. S. Islam, M. Rahimi, D. Ruiz Carrascal, J. Sillmann, M. B. Sylla, C. Tebaldi, W. Wang, R. Zaaboul, 2021, Climate Change Information for Regional Impact and for Risk Assessment. In: Climate Change 2021: The Physical Science Basis. Contribution of Working Group I to the Sixth Assessment Report of the Intergovernmental Panel on Climate Change [Masson-Delmotte, V., P. Zhai, A. Pirani, S. L. Connors, C. Péan, S. Berger, N. Caud, Y. Chen, L. Goldfarb, M. I. Gomis, M. Huang, K. Leitzell, E. Lonnoy, J. B. R. Matthews, T. K. Maycock, T. Waterfield, O. Yelekçi, R. Yu and B. Zhou (eds.)]. Cambridge University Press

31 Committee on Climate Change (2021) Independent Assessment of UK Climate Risk. https://www.theccc.org.uk/publication/independent-assessment-of-uk-climate-risk/

32 Brown, K. (2020). How much more climate change is inevitable for the UK? Committee on Climate Change. 
https://www.theccc.org.uk/2020/04/21/how-much-more-climate-change-is-inevitable-for$\underline{\text { the-ukl }}$

33 Committee on Climate Change (2016) based on Warren, R. et al. 2016 for the ASC. A meta-analysis of how climate change risk in the UK accrues with global annual mean temperature rise. UK Climate Change Risk Assessment 2017, Synthesis Report.

https://www.theccc.org.uk/uk-climate-change-risk-assessment-2017/

34 Ranasinghe, R., A. C. Ruane, R. Vautard, N. Arnell, E. Coppola, F. A. Cruz, S.

Dessai, A. S. Islam, M. Rahimi, D. Ruiz Carrascal, J. Sillmann, M. B. Sylla, C. Tebaldi, W. Wang, R. Zaaboul, 2021, Climate Change Information for Regional Impact and for Risk Assessment. In: Climate Change 2021: The Physical Science Basis. Contribution of Working Group I to the Sixth Assessment Report of the Intergovernmental Panel on Climate Change [Masson-Delmotte, V., P. Zhai, A. Pirani, S. L. Connors, C. Péan, S. Berger, N. Caud, Y. Chen, L. Goldfarb, M. I. Gomis, M. Huang, K. Leitzell, E. Lonnoy, J. B. R. Matthews, T. K. Maycock, T. Waterfield, O. Yelekçi, R. Yu and B. Zhou (eds.)]. Cambridge University Press

35 Palmer, M, et al. (2018) UK Climate Projections Marine Report, Met Office

https://www.metoffice.gov.uk/binaries/content/assets/metofficegovuk/pdf/research/ukcp/ ukcp18-marine-report-updated.pdf

36 Committee on Climate Change (2021) Independent Assessment of UK Climate Risk, https://www.theccc.org.uk/publication/independent-assessment-of-uk-climate-risk/

37 Brown, K (2020) How much more climate change is inevitable for UK? Committee on Climate Change.

https://www.theccc.org.uk/2020/04/21/how-much-more-climate-change-is-inevitable-for$\underline{\text { the-ukl }}$

38 Warren, R. et al. for the ASC (2016) in UK Climate Change Risk Assessment 2017, Synthesis Report.

https://www.theccc.org.uk/wp-content/uploads/2016/07/UK-CCRA-2017-SynthesisReport-Committee-on-Climate-Change.pdf

39 Committee on Climate Change (2021) Independent Assessment of UK Climate Risk, https://www.theccc.org.uk/publication/independent-assessment-of-uk-climate-risk/

40 Hajat, S. et al. (2014). Climate Change effects on human health: projections of temperature- related mortality for the UK during the 2020s, 2050s and 2080s. JECH.

https://jech.bmj.com/content/68/7/641

41 Committee on Climate Change (2021) UK Climate Risk Independent Assessment. Technical Report, Ch. 5, Health, Communities and the Built Environment.

https://www.ukclimaterisk.org/wp-content/uploads/2021/06/CCRA3-Chapter-5FINAL.pdf 
42 Committee on Climate Change (2021) UK Climate Risk Independent Assessment. Technical Report, Ch. 5, Health, Communities and the Built Environment.

https://www.ukclimaterisk.org/wp-content/uploads/2021/06/CCRA3-Chapter-5FINAL.pdf

43 The Committee on Climate Change (2016) UK Climate Change Risk Assessment 2017, Cross-cutting issues.

https://www.theccc.org.uk/wp-content/uploads/2016/07/UK-CCRA-2017-Chapter-8Cross-cutting-issues.pdf

44 UNESCO WWAP (2018) Nature based solutions for water.

http://www.unesco.org/new/en/natural-sciences/environment/water/wwap/wwdr/2018nature-based-solutions/

45 The Committee on Climate Change (2016) Climate Change Risk Assessment 2017 Evidence Report, Business and Industry.

https://www.theccc.org.uk/uk-climate-change-risk-assessment-2017/ccrachapters/business-and-industry/

46 The Committee on Climate Change (2016) UK Climate Change Risk Assessment 2017, Cross-cutting issues.

https://www.theccc.org.uk/wp-content/uploads/2016/07/UK-CCRA-2017-Chapter-8Cross-cutting-issues.pdf

47 The Committee on Climate Change (2016), UK Climate Risk Assessment 2017, Business and industry.

https://www.theccc.org.uk/wp-content/uploads/2016/07/UK-CCRA-2017-Chapter-6Business-and-industry.pdf

48 The Committee on Climate Change (2016), UK Climate Risk Assessment 2017, Synthesis Report.

https://www.theccc.org.uk/uk-climate-change-risk-assessment-2017/synthesis-report/

49 Committee on Climate Change, (2016) UK Climate Change Risk Assessment 2018, Cross-cutting issues.

https://www.theccc.org.uk/wp-content/uploads/2016/07/UK-CCRA-2017-Chapter-8Cross-cutting-issues.pdf

50 Walker, G. et al. (2008) Addressing Environmental Inequalities: Flood Risk. EA Project ref SC020061/SR1. Environment Agency, Bristol, UK.

https://assets.publishing.service.gov.uk/government/uploads/system/uploads/attachmen t data/file/291063/scho0905bjok-e-e.pdf

51 Watkiss, P. et al. (2016) Climate Change Impacts on the Future Cost of Living (SSC/CCC004). Joseph Rowntree Foundation, York.

https://www.climatejust.org.uk/sites/default/files/FINAL\%20Watkiss\%20report\%2030032 016.pdf 
52 Britain's coastal towns - ONS (2020)

https://www.ons.gov.uk/businessindustryandtrade/tourismindustry/articles/coastaltownsi nenglandandwales/2020-10-06

53 HM Treasury (2020) Net zero review: interim report.

https://www.gov.uk/government/publications/net-zero-review-interim-report

54 Shuckburgh, E. et al. (2020). A Blueprint for a Green Future - Multidisciplinary report on a green recovery from COVID-19 by the Cambridge Zero Policy Forum. Cambridge Zero, University of Cambridge.

https://www.cambridge.org/engage/coe/article-details/5fa1b3a118fd43001231c78f

55 Cohen, M.G. (ed) (2017) Climate change and gender in rich countries. Routledge.

https://books.google.co.uk/books/about/Climate Change and Gender in Rich Countr. html?id=8XilAQAACAAJ\&redir esc=y

56 Dunne, D. (2020) Mapped: How climate change disproportionately affects women's health. CarbonBrief.

https://www.carbonbrief.org/mapped-how-climate-change-disproportionately-affectswomens-health

57 Mason, V. et al. (2010) The psychological impact of exposure to floods. Psychology, Health \& Medicine.

https://doi.org/10.1080/13548500903483478

58Tunstall, S. et al. (2006) The health effects of flooding: social research results from England and Wales. Journal of Water and Health. https://doi.org/10.2166/wh.2006.031

59 Paranjothy, S. et al. (2011) Psychosocial impact of the summer 2007 floods in England. BMC Public Health.

https://bmcpublichealth.biomedcentral.com/articles/10.1186/1471-2458-11-145

60 Ray, G. et al. (2007) The impact of major heat waves on all-cause and causespecific mortality in France from 1971 to 2003. International Archives of Occupational and Environmental Health. https://link.springer.com/article/10.1007/s00420-007-0173-4

61 TCFD (2017) Recommendations of the Task Force on Climate-related Financial Disclosures. https://www.fsb-tcfd.org/publications/

62 Murray, J. (2021) Moody's: Net zero pledges trigger credit squeeze. GreenBiz.

https://www.greenbiz.com/article/moodys-net-zero-pledges-trigger-credit-squeeze

63 DEFRA (2018) The National Adaptation Programme and Third Strategy for Climate Adaptation Reporting.

https://assets.publishing.service.gov.uk/government/uploads/system/uploads/attachmen t data/file/727252/national-adaptation-programme-2018.pdf

64 HM Government (2018) A Green Future: Our 25 Year Plan to Improve the Environment. 
https://assets.publishing.service.gov.uk/government/uploads/system/uploads/attachmen $\mathrm{t}$ data/file/693158/25-year-environment-plan.pdf

65 Scottish Government (2019) Climate Ready Scottland: climate change and adaptation programme 2019-2024. https://www.gov.scot/publications/climate-readyscotland-second-scottish-climate-change-adaptation-programme-2019-2024/pages/6/

66 Department of the Environment, North Ireland (2019), Northern Ireland Climate Change and Adaptation Programme 2019-2024. https://www. daerani.gov.uk/publications/northern-ireland-climate-change-adaptation-programme-2019$\underline{2024}$

67 Welsh Government (2019), Prosperity for all: A climate conscious Wales.

https://gov.wales/prosperity-all-climate-conscious-wales

68 DEFRA (2018) The National Adaptation Programme and Third Strategy for Climate Adaptation Reporting.

https://assets.publishing.service.gov.uk/government/uploads/system/uploads/attachmen t data/file/727252/national-adaptation-programme-2018.pdf

69 DEFRA (2018) The National Adaptation Programme and Third Strategy for Climate Adaptation Reporting.

https://assets.publishing.service.gov.uk/government/uploads/system/uploads/attachmen $\mathrm{t}$ data/file/727252/national-adaptation-programme-2018.pdf

70 E. Cox \& Edwards, N.R. (2019) Beyond carbon pricing: policy levers for negative emissions technologies. Climate Policy.

https://www.tandfonline.com/doi/abs/10.1080/14693062.2019.1634509?needAccess=tr ue\&journalCode=tcpo20

71 NFU (2019) Achieving Net Zero: Farming's 2040 Goal.

https://www.nfuonline.com/nfu-online/business/regulation/achieving-net-zero-farmings2040-goal/

72 H. J. Buck (2016) Rapid scale-up of negative emissions technologies: social barriers and social implications. Climate Change.

https://link.springer.com/article/10.1007/s10584-016-1770-6

73 Rohr, C. et al (2016) Travel in Britain in 2035: Technology innovation. RAND.

https://www.rand.org/pubs/research reports/RR1377.html

74 Fuhrman, J. et al. (2019) From Zero to Hero?: Why Integrated Assessment Modelling of Negative Emissions Technologies Is Hard and How We Can Do Better. Frontiers in Climate. https://www. frontiersin.org/articles/10.3389/fclim.2019.00011/full

75 Fridahl, F. and M. Lehtveer (2018) Bioenergy with carbon capture and storage (BECCS): Global potential, investment preferences, and deployment barriers. Energy Research \& Social Science.

https://www.sciencedirect.com/science/article/pii/S2214629618302998

76 Fuhrman, J. et al. (2010) Food-energy-water implications of negative emissions technologies in $\mathrm{a}+1.5^{\circ} \mathrm{C}$ future. Nature Climate Change.

https://www.nature.com/articles/s41558-020-0876-z?proof $=\mathrm{t}$ 
77 Aggarwal, A. and D. Brockington (2020) Reducing or creating poverty? Analyzing livelihood impacts of forest carbon projects with evidence from India. Land Use Policy. https://ideas.repec.org/a/eee/lauspo/v95y2020ics0264837719317272.html

78 Burke, J, Fankhauser, S, Kazaglis, A, Kessler, L, Khandelwal, N, Bolk, J, O’Boyle, P, (2020) Distributional impacts of a carbon tax in the UK, Report 1: Analysis by household type https://www.Ise.ac.uk/granthaminstitute/wp-

content/uploads/2020/03/Distributional-impacts-of-a-UK-carbon-tax Report-1 analysisby-household-type.pdf

79 Climate Financial Risk forum (2020) Climate financial risk forum guide 2020, innovation. https://www.fca.org.uk/publication/corporate/climate-financial-risk-forumguide-2020-innovation-chapter.pdf

80 R. Bellamy (2018) Incentivize negative emissions responsibly. Nature Energy. https://www.nature.com/articles/s41560-018-0156-6

81 Party Parliamentary Group on the Green New Deal (2020). How to reset. 2020. https://reset-uk.org/

82 Bray, R. and Ford, R. (2021), Briefing paper: Energy justice POINTs: Politics to create a more sustainable and fairer future for all.

https://strathprints.strath.ac.uk/76421/

83 Party Parliamentary Group on the Green New Deal (2020). How to reset. 2020.

https://reset-uk.org/

84 HM Treasury (2021) Build back better. Policy paper.

https://www.gov.uk/government/publications/build-back-better-our-plan-for-growth/buildback-better-our-plan-for-growth-html

85 Wales Trades Union Congress (2020) A green recovery and a just transition. https://www.tuc.org.uk/green

86 S. Fuss et al., Moving toward Net-Zero Emissions Requires New Alliances for Carbon Dioxide Removal One Earth.

https://www.cell.com/one-earth/pdf/S2590-3322(20)30365-1.pdf

87 Bray, R. and Ford, R. (2021), Briefing paper: Energy justice POINTs: Politics to create a more sustainable and fairer future for all.

https://strathprints.strath.ac.uk/76421/

88 Evensen et al (2018) The relationship between justice and acceptance of energy transition costs in UK. Applied Energy.

https://www.researchgate.net/publication/324598561 The relationship between justice and acceptance of energy transition costs in the UK

89 Climate Assembly UK (2020) The path to net zero. 
https://www.climateassembly.uk/report/

90 Bray, R. and Ford, R. (2021), Briefing paper: Energy justice POINTs: Politics to create a more sustainable and fairer future for all.

https://strathprints.strath.ac.uk/76421/

91 Traynor, K. and Simpson, G. (2020) SAFE regeneration report. University of Liverpool.

https://www.powertochange.org.uk/wp-content/uploads/2020/02/SAFE-Regenerationreport-V4-Digital.pdf

92 Wittmayer et al. (2021) Contributing to sustainable and just energy systems? The mainstreaming of renewable energy prosumerism within and across institutional logics. Energy Policy.

https://doi.org/10.1016/j.enpol.2020.112053

93 Burke, M. J. \& Stephens, J. C. (2018). Political power and renewable energy futures: a critical review. Energy Res. Social Sci. 35, 78-93.

https://www.sciencedirect.com/science/article/pii/S2214629617303468

94 Wales Trades Union Congress (2020) A green recovery and a just transition.

https://www.tuc.org.uk/green

95 HM Government Press Release (2021) UK enshrines new target in law to slash emissions by $78 \%$ by 2035 .

https://www.gov.uk/government/news/uk-enshrines-new-target-in-law-to-slashemissions-by-78-by-2035

96 Climate Change Committee (2020), The Sixth Carbon Budget: the UK's path to Net Zero.

https://www.theccc.org.uk/publication/sixth-carbon-budget/

97 Andrews-Speed, P. (2016) Applying institutional theory to the low-carbon energy transition. Energy Research \& Social Science.

https://doi.org/10.1016/i.erss.2015.12.011

98 Bank of England (2021) Key elements of the 2021 Biennial Exploratory Scenario: Financial risks from climate change

https://www.bankofengland.co.uk/stress-testing/2021/key-elements-2021-biennialexploratory-scenario-financial-risks-climate-change

99 European Union Aviation Safety Agency (2019) European Aviation Environmental Report 2019.

https://www.easa.europa.eu/eaer/system/files/usr uploaded/219473 EASA EAER 201 9 WEB HI-RES 190311.pdf 
100 International Air Transport Association (2019) The Impact of Climate Change on Aviation.

https://www.iata.org/contentassets/0772118eec2e40bbba472b862e4f45ec/sfo2019day3-climate-change.pdf

101 Climate Change Committee (2020), The Sixth Carbon Budget, Sector Summaries: Aviation

https://www.theccc.org.uk/wp-content/uploads/2020/12/Sector-summary-Aviation.pdf

102 Renewable UK (2020) Wind and Aviation: A collaborative approach to decarbonisation?

https://www.blog.renewableuk.com/post/wind-and-aviation

103 WEF and McKinsey \& Co. (2020) Clean Skies for Tomorrow: Sustainable Aviation Fuels as a Pathway to Net-Zero Aviation.

https://www.weforum.org/reports/clean-skies-for-tomorrow-sustainable-aviation-fuelsas-a-pathway-to-net-zero-aviation/

104 HM Government (2021) Net Zero Strategy: Build Back Better.

https://assets.publishing.service.gov.uk/government/uploads/system/uploads/attachmen $\mathrm{t}$ data/file/1028157/net-zero-strategy.pdf

105 Roland Berger (2020) Sustainable aviation fuels key for the future of air travel.

https://www.rolandberger.com/en/Insights/Publications/Sustainable-aviation-fuels-keyfor-the-future-of-air-travel.html

106 Lidia Kleshchenko \& Anja von der Ropp (2020) Green Innovation for Global Aviation. World Intellectual Property Organization (WIPO) Green.

https://www3.wipo.int/wipogreen/en/news/2020/news 0047.html

107 United Nations World Tourism Organization (2007) Davos declaration: climate change and tourism responding to global challenges

https://www.e-unwto.org/doi/book/10.18111/9789284412341

108 Hares, A. et al. (2010) Climate change and the air travel decisions of UK tourists. Journal of Transport Geography.

https://www.sciencedirect.com/science/article/abs/pii/S096669230900101X

109 Marteau, T.M. (2017) Towards environmentally sustainable human behaviour: targeting non-conscious and conscious processes for effective and acceptable policies. Phil. Trans. R. Soc.

http://dx.doi.org/10.1098/rsta.2016.0371

110 Sustainable Aviation (2020) Comprehensive Spending Review Submission.

https://www.sustainableaviation.co.uk/wp-content/uploads/2020/10/SustainableAviation-CSR-Submission-FINAL-240920.pdf 
111 British Airways (2020) Sustainability at British Airways.

https://mediacentre.britishairways.com/factsheets/details/86/Factsheets-3/208

112 British Airways (2020) Sustainability at British Airways.

https://mediacentre.britishairways.com/factsheets/details/86/Factsheets-3/208

113 Dietz et al. (2016) Climate value at risk' of global financial assets. Nature Climate Change, letters.

https://www.politico.eu/wp-content/uploads/2016/04/Dietz-et-al-201612-copy.pdf

114 Bank of England (2020) Climate Change: What are the risks to financial stability? https://www.bankofengland.co.uk/knowledgebank/climate-change-what-are-the-risks-tofinancial-stability

115 Climate Financial Risk Forum (2020), Climate Financial Risk Forum Guide 2020, Innovation Chapter

https://www.fca.org.uk/publication/corporate/climate-financial-risk-forum-guide-2020innovation-chapter.pdf

116 FCA (2020), Climate Financial Risk Forum Guide 2020.

https://www.fca.org.uk/publication/corporate/climate-financial-risk-forum-guide-2020summary.pdf

117 IPCC (2018) Special Report on Global Warming of 1.5'C.

https://www.ipcc.ch/sr15/

$118 \mathrm{~J}$. Fuhrman, et al. (2019) Why Integrated Assessment Modeling of Negative Emissions Technologies Is Hard and How We Can Do Better. Frontiers in Climate.

http://arxiv-export-lb.library.cornell.edu/abs/2010.06723

119 Scott, S. Gilfillan et al. (2013) Last chance for carbon capture and storage. Nature Climate Change.

https://www.nature.com/articles/nclimate1695?message-global=remove

120 Climate Change Committee (2020), The Sixth Carbon Budget Sector Summaries; Greenhouse Gas Removals.

https://www.theccc.org.uk/wp-content/uploads/2020/12/Sector-summary-GHGremovals.pdf

121 HM Government (2021) Net Zero Strategy: Build Back Greener. https://assets.publishing.service.gov.uk/government/uploads/system/uploads/attachmen $\mathrm{t}$ data/file/1028157/net-zero-strategy.pdf

122 P. Smith, et al. (2015) Biophysical and economic limits to negative CO2 emissions. Nature Climate Change.

https://abdn.pure.elsevier.com/en/publications/biophysical-and-economic-limits-tonegative-co2-emissions 
123 Platt et al. (2018.) A novel approach to assessing the commercial opportunities for greenhouse gas removal technology value chains: Developing the case for a negative emissions credit in the UK. Journal of Cleaner Production.

https://doi.org/10.1016/j.jclepro.2018.08.291

124 Deloitte (2020) Is carbon sequestration a viable option for reducing carbon tax?

https://www2.deloitte.com/za/en/pages/tax/articles/is-carbon-sequestration-a-viableoption-for-reducing-carbon-tax.html

125 J. Fuhr et al. (2019) From Zero to Hero?: Why Integrated Assessment Modeling of Negative Emissions Technologies Is Hard and How We Can Do Better. Frontiers in Climate. Link https://www.frontiersin.org/articles/10.3389/fclim.2019.00011/full

126 Peters, G. and Geden, O. (2017) Catalysing a political shift from low to negative carbon Nature Climate Change.

https://cicero.oslo.no/en/publications/external/4788

127 Daggash, h. and Mac Dowell, N. (2010) Higher Carbon Prices on Emissions Alone Will Not Deliver the Paris Agreement. Joule.

https://www.cell.com/joule/pdfExtended/S2542-4351(19)30383-6

128 Jenkins, S. et al. (2020) Sustainable financing of a permanent CO2 disposal through a Carbon Takeback Obligation. https://arxiv.org/pdf/2007.08430.pdf

129 WEF and McKinsey \& Company (2021) Nature and Net Zero.

https://www.mckinsey.com/ /media/mckinsey/business $\% 20$ functions/sustainability/our\% 20insights/why $\% 20$ investing $\% 20$ in $\% 20$ nature $\% 20$ is $\% 20$ key $\% 20$ to $\% 20$ climate $\% 20$ mitig ation/nature-and-net-zero-vf.pdf

130 Griscom, B.W. (2017) Natural climate solutions. PNAS.

https://www.pnas.org/content/pnas/114/44/11645.full.pdf

131 The Wildlife Trusts (2020) Let Nature Help.

https://www.bbowt.org.uk/sites/default/files/2020-06/Let\%20Nature\%20Help.pdf 132 Royal Academy of Engineering (2017) Greenhouse gas removal. The Royal Society. https://royalsociety.org/-/media/policy/projects/greenhouse-gas-removal/royalsociety-greenhouse-gas-removal-report-2018.pdf

133 Royal Academy of Engineering (2017) Greenhouse gas removal. The Royal Society. https://royalsociety.org/-/media/policy/projects/greenhouse-gas-removal/royalsociety-greenhouse-gas-removal-report-2018.pdf

134 Pozo, C. et al. Equity in allocating carbon dioxide removal quotas. Nature Climate Change. https://www.nature.com/articles/s41558-020-0802-4?proof=t

135 Climate Change Committee (2020), Sixth Carbon Budget Sector Summaries:

Buildings https://www.theccc.org.uk/wp-content/uploads/2020/12/Sector-summary-

Buildings.pdf 
136 WGBC (2020) Advancing Net Zero 2020. https://www.worldgbc.org/advancing-netzero-status-report-2020

137 Deloitte (2010) Deloitte construction predictions 2020.

https://www2.deloitte.com/ce/en/pages/real-estate/articles/construction-predictions2020.html

138 UKGBC (2020) Building the Case for Net Zero. https://www.ukgbc.org/wpcontent/uploads/2020/09/Building-the-Case-for-Net-Zero UKGBC.pdf

139 UK Steel (2020) Submission to the Energy and Environment Sub-Committee's evidence session on Carbon Border Adjustment Mechanism.

https://committees.parliament.uk/writtenevidence/781/pdf/

140 Allwood, J. et al. (2019) Steel arising: opportunities for the UK in a transforming global steel industry. University of Cambridge. https://doi.org/10.17863/CAM.40835

141 Dunster, A. \& Gall, D (2016) Alkali-activated binders for precast and ready-mixed concrete products: A route map to standardisation, certification and guidance. BRE Press. https://www.brebookshop.com/details.jsp?id=327732

142 HACT (2020) Do the smart thing: The future the social smart home https://hact.org.uk/sites/default/files/DoTheSmartThing Final.pdf

143 Deloitte (2010) Deloitte construction predictions 2020.

https://www2.deloitte.com/ce/en/pages/real-estate/articles/construction-predictions2020.html

144 McCulley, R. (2010) Oil and gas companies have direct air capture technology in their sights. Upstream, Energy Explore, 2020, 2 November.

https://www.upstreamonline.com/environment/oil-and-gas-companies-have-direct-aircapture-technology-in-their-sights/2-1-902736

145 Committee on Climate Change (2020), The Sixth Carbon Budget Sector

Summaries: Electricity Generation https://www.theccc.org.uk/wpcontent/uploads/2020/12/Sector-summary-Electricity-generation.pdf

146 C. Beuttler et al. (2019) The Role of Direct Air Capture in Mitigation of Anthropogenic Greenhouse Gas Emissions. Frontiers in Climate. https://www.frontiersin.org/articles/10.3389/fclim.2019.00010/full

147 Committee on Climate Change (2020). The 6th Carbon Budget Sector Summary: Electricity Generation. https://www.theccc.org.uk/wp-content/uploads/2020/12/Sectorsummary-Electricity-generation.pdf

148 Evans, S. (2017) Analysis: UK auction reveals offshore wind cheaper than new gas. CarbonBrief. https://www.carbonbrief.org/analysis-uk-auction-offshore-wind-cheaperthan-new-gas

149 UKRI (2020) Low-cost nuclear challenge. https://www.ukri.org/our-work/our-mainfunds/industrial-strategy-challenge-fund/clean-growth/low-cost-nuclear-challenge/ 
150 Radcliffe, J, Murrant, D, \& Joshi, A (2020) UK Roadmap for Energy Storage Research and Innovation. University of Birmingham.

https://ukesr.supergenstorage.org/chapters/energy-storage-technologies/

151 Wuebbles, D.J. \& Sanyal, S. (2015). Air Quality in a Cleaner Energy World. Air

Pollution. https://link.springer.com/article/10.1007/s40726-015-0009-x

152 IRENA (2019) Renewable power generation costs in 2019.

https://www.irena.org/publications/2020/Jun/Renewable-Power-Costs-in-2019

153 Climate Change Committee (2020). Sixth Carbon Budget Sector Summary: Surface

Transport: https://www.theccc.org.uk/wp-content/uploads/2020/12/Sector-summary-

Surface-transport.pdf

154 Ainalis D. T., Thorne C., and Cebon D (2020) White Paper: Decarbonising the UK's Long-Haul Road Freight at Minimum Economic Cost. Centre for Sustainable Road Freight. http://www.csrf.ac.uk/wp-content/uploads/2020/07/SRF-WP-UKEMS-v2.pdf

155 Brand, C. et al. (2020) The climate change mitigation effects of daily active travel in cities. https://www.researchsquare.com/article/rs-39219/v1

156 Institute of Mechanical engineers (2020) Automatic Vehicles: Automatically Low Carbon?

https://www.zemo.org.uk/assets/reports/Automated \%20Vehicles $\% 20$ brochure $\% 20$ WEB \%20VERSION.pdf

157 LSE (2020) Seizing sustainable growth opportunities from zero emission passenger vehicles in the UK. https://www.Ise.ac.uk/granthaminstitute/publication/seizingsustainable-growth-opportunities-from-zero-emission-passenger-vehicles-in-the-uk/

158 Barr, S. \& Prillwitz, J. (2014) A Smarter Choice? Exploring the Behaviour Change Agenda for Environmentally Sustainable Mobility. Environment and Planning C: Politics and Space. https://doi.org/10.1068/c1201

159 Maibach, E. et al. (2009) Promoting physical activity and reducing climate change: Opportunities to replace short car trips with active transportation. Preventive Medicine. https://doi.org/10.1016/j.ypmed.2009.06.028

160 Shell \& Deloitte (2021) Decarbonising Road Freight.

https://www2.deloitte.com/global/en/pages/energy-and-

resources/articles/decarbonizing-road-freight.html

161 LSE (2020) Seizing sustainable growth opportunities from zero emission passenger vehicles in the UK https://www.Ise.ac.uk/granthaminstitute/publication/seizing-

sustainable-growth-opportunities-from-zero-emission-passenger-vehicles-in-the-uk/

162 Climate Change Committee (2020). The Sixth Carbon Budget Sector Summaries:

Agriculture and Land Use, Land Use Change and Forestry

https://www.theccc.org.uk/wp-content/uploads/2020/12/Sector-summary-Agriculture-

land-use-land-use-change-forestry.pdf

163 HM Government (2018) A Green Future: Our 25 year plan to Improve the Environment. 
https://assets.publishing.service.gov.uk/government/uploads/system/uploads/attachmen $\mathrm{t}$ data/file/693158/25-year-environment-plan.pdf

164 P. Smith et al. (2015) Biophysical and economic limits to negative CO2 emissions. Nature Climate Change. https://www.nature.com/articles/nclimate2870

165 Coe, S. \& Finlay, J. (2020) The Agriculture Act 2020, Briefing Paper.

https://commonslibrary.parliament.uk/research-briefings/cbp-8702/

166 E. Cox et al. (2020) Public perceptions of carbon dioxide removal in the United States and the United Kingdom. Nature Climate Change.

https://www.nature.com/articles/s41558-020-0823-z

167 Committee on Climate Change (2020) The Sixth Carbon Budget - The UK's path to Net Zero. https://www.theccc.org.uk/publication/sixth-carbon-budget/

168 Achieving Net Zero, Farming's 2040 goal (2020) National Farmer's Union of

England and Wales https://www. nfuonline.com/nfu-

online/business/regulation/achieving-net-zero-farmings-2040-goal/

169 Achieving Net Zero, Farming's 2040 goal (2020) National Farmer's Union of

England and Wales https://www. nfuonline.com/nfu-

online/business/regulation/achieving-net-zero-farmings-2040-goal/

170 De Clercq, M. et al. (2018) Agriculture 4.0: The Future of farming technology. Oliver Wyman. https://www.oliverwyman.com/content/dam/oliver-

wyman/v2/publications/2021/apr/agriculture-4-0-the-future-of-farming-technology.pdf

171 Accenture Strategy (2017) The future of food: new realities for the industry.

https://www.accenture.com/us-en/ acnmedia/pdf-70/accenture-future-of-food-new-

realities-for-the-industry.pdf

172 McKinsey and Company (2020) Agriculture and Climate Change.

https://www.mckinsey.com/ /media/mckinsey/industries/agriculture/our\%20insights/redu cing $\% 20$ agriculture $\% 20$ emissions $\% 20$ through $\% 20$ improved $\% 20$ farming $\% 20$ practices/a griculture-and-climate-change.pdf

173 FFCC (2020) Farming smarter: the case for agroecological enterprise.

https://ffcc.co.uk/assets/downloads/FFCC-2020-Farming-Smarter-The-case-for-

agroecological-enterprise.pdf

174 Barclays (2021) Insight to Al in UK agritech.

https://www.barclays.co.uk/content/dam/documents/business/business-

insight/Insights $\mathrm{Al}$ in Agriculture.pdf

175 Ellen McArthur Foundation (2019) Cities and circular economy for food.

https://www.ellenmacarthurfoundation.org/assets/downloads/Cities-and-Circular-

Economy-for-Food 280119.pdf

176 Stubbs, R.J. et al. (2018) Responding to food, environment and health challenges by changing meat consumption behaviours in consumers. Nutrition Bulletin.

https://onlinelibrary. wiley.com/doi/full/10.1111/nbu.12318?casa token=zTW2xOLfeLOAA AAA\%3AG1n9FtLPY-uumoX8D-

VaobFynEA7XnIONxVQGAE5xjdzTElbnysIAxL5CK0QFcXjUrtlKnc4YxDshC8 
177 Marteau, T.M. (2017) Towards environmentally sustainable human behaviour: targeting non-conscious and conscious processes for effective and acceptable policies. Phil. Trans. R. Soc. http://dx.doi.org/10.1098/rsta.2016.0371 